OAK RIDGE
NATIONAL LABORATORY

MANAGED BY UT-BATTELLE FOR THE DEPARTMENT OF ENERGY
ORNL/TM-2012/139

\section{Initial Examination of Low Velocity Sphere Impact of Glass Ceramics}

T. G. Morrissey, E. E. Fox, A. A. Wereszczak, ${ }^{*}$ and M. K. Ferber Ceramic Science and Technology Group Materials Science and Technology Division Oak Ridge National Laboratory

Oak Ridge, TN 37831-6068

* Corresponding Author: wereszczakaa@ornl.gov

Publication Date: June 2012

Prepared by the OAK RIDGE NATIONAL LABORATORY

Oak Ridge, Tennessee 37831 managed by

UT-BATTELLE, LLC for the U.S. DEPARTMENT OF ENERGY Under contract DE-AC05-00OR22725

US ARMY TARDEC

DISTRIBUTION STATEMENT A.

UT-BATTELLE ORNL-27 (4-00)
Approved for public release; distribution unlimited. 


\section{DOCUMENT AVAILABILITY}

Reports produced after January 1, 1996, are generally available free via the U.S. Department of Energy (DOE) Information Bridge:

Web site: $h$ ttp://www.osti.gov/bridge

Reports produced before January 1, 1996, may be purchased by members of the public from the following source:

National Technical Information Service

5285 Port Royal Road

Springfield, VA 22161

Telephone: 703-605-6000 (1-800-553-6847)

TDD: $703-487-4639$

Fax: 703-605-6900

E-mail: info@ntis.fedworld.gov

Web site: http://www.ntis.gov/support/ordernowabout.htm

Reports are available to DOE employees, DOE contractors, Energy Technology Data Exchange (ETDE) representatives, and International Nuclear Information System (INIS) representatives from the following source:

Office of Scientific and Technical Information

P.O. Box 62

Oak Ridge, TN 37831

Telephone: 865-576-8401

Fax: 865-576-5728

E-mail: reports@osti.gov

Web site: http://www.osti.gov/contact.html

This report was prepared as an account of work sponsored by an agency of the United States Government. Neither the United States government nor any agency thereof, nor any of their employees, makes any warranty, express or implied, or assumes any legal liability or responsibility for the accuracy, completeness, or usefulness of any information, apparatus, product, or process disclosed, or represents that its use would not infringe privately owned rights. Reference herein to any specific commercial product, process, or service by trade name, trademark, manufacturer, or otherwise, does not necessarily constitute or imply its endorsement, recommendation, or favoring by the United States Government or any agency thereof. The views and opinions of authors expressed herein do not necessarily state or reflect those of the United States Government or any agency thereof. 


\section{TABLE OF CONTENTS}

\section{Page}

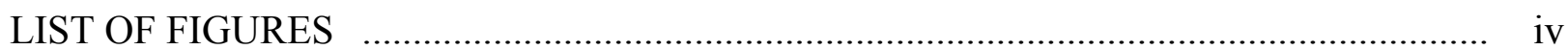

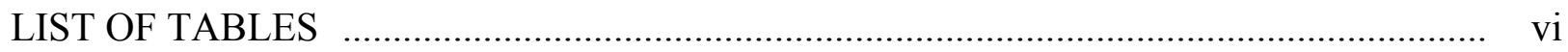

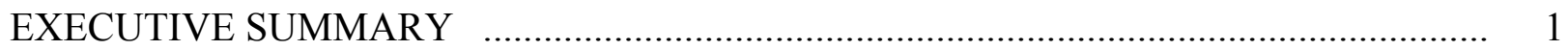

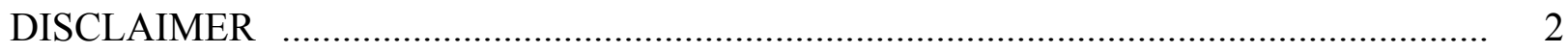

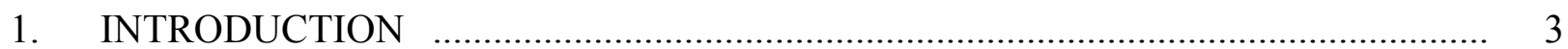

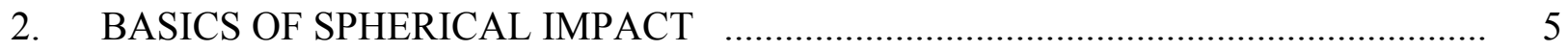

2.1. Estimating Impact Force from Impact Velocity $\quad$............................................... 5

2.2. Comparing Different Sphere Materials .......................................................... 7

2.3. Ring Crack Initiation at Dynamic vs. Quasi-Static Conditions ......................... 9

3. GAS GUN, DROP TEST, TARGET GLASS, SPHERE IMPACTERS, AND SABOT 10

3.1. Gas Gun Description ............................................................................ 10

3.2. Drop Test Description ............................................................................ 13

3.3. Target Glass Description ........................................................................ 13

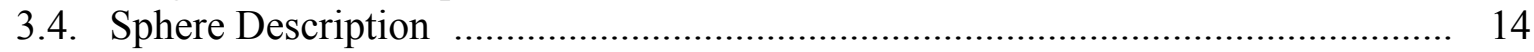

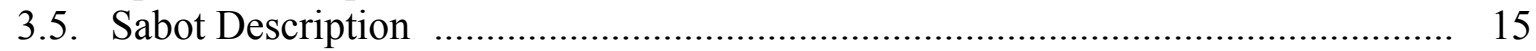

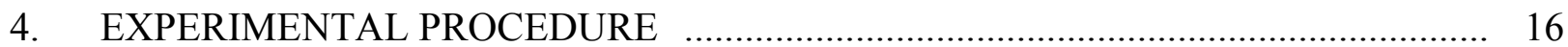

4.1. Gas Gun Calibration, Drop Test Calibration, and Unit Conversions ................ 16

4.2. Gas Gun Impact Test Procedure ................................................................ 18

4.3. Drop Impact Test Procedure ...................................................................... 19

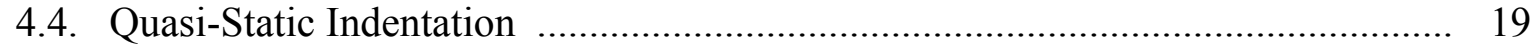

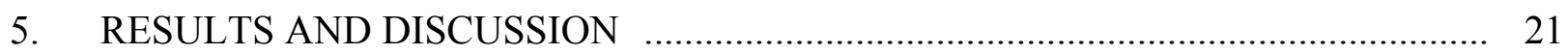

5.1. Impact Response and Comparison ....................................................... 21

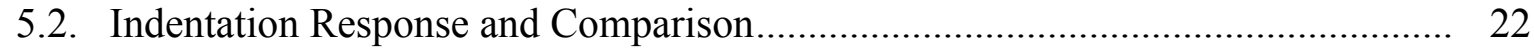

5.3. Location Dependent Indentation Response ............................................ 28

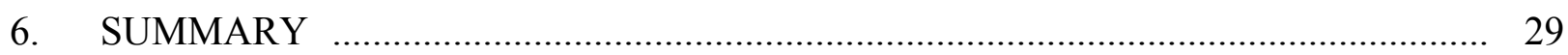

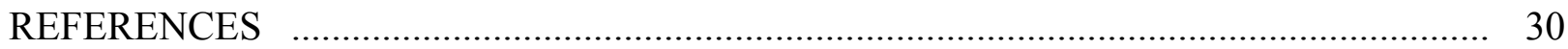

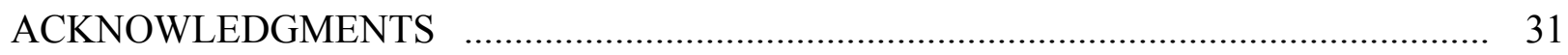

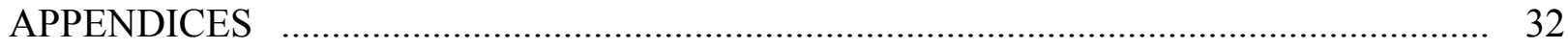




\section{LIST OF FIGURES}

Figure

Page

1. Gas gun assembly for low velocity sphere impact testing. .................................. 10

2. Illustration of velocity measurement. .......................................................... 11

3. Top view showing end of barrel (left), velocity measurement device, and target glass (right of circular cut-out).

4. Drop test setup using the velocity measurement system, cutout showing impact area with target glass below.

5. Photograph of glass-ceramic tiles Resistan ${ }^{\mathrm{TM}_{-} \mathrm{G} 1}$ (left) and Resistan ${ }^{\mathrm{TM}_{-} \mathrm{L}}$ (right). $\quad \ldots . .13$

6. Spheres used for impact testing (from left to right): borosilicate (BS) glass, soda-lime silicate (SLS) glass, silicon nitride $\left(\mathrm{Si}_{3} \mathrm{~N}_{4}\right)$, alumina $\left(\mathrm{Al}_{2} \mathrm{O}_{3}\right)$, zirconia $\left(\mathrm{ZrO}_{2}\right)$, steel (carbon), and steel (chrome).

7. Gas gun pressure and resulting velocity.

8. Relationship between drop height of spheres, resulting measured velocity, and resulting impact velocity corrected for continued acceleration due to gravity below velocity measurement system.

9. Velocity conversions between $\mathrm{m} / \mathrm{s}, \mathrm{mph}$, and $\mathrm{ft} / \mathrm{s}$.

10. Schematic drawing of the ring crack initiation test configuration. An acoustic emission sensor was used to detect an acoustic event that was then linked to the ring crack initiation force. Target material is glass tile.

11. RCIF as a function of sphere material elastic modulus for glass ceramic

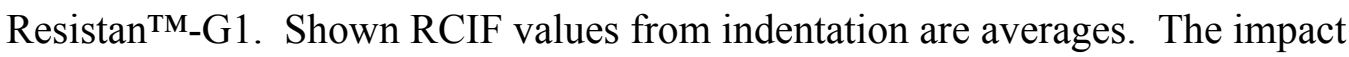
response of $\mathrm{Si}_{3} \mathrm{~N}_{4}$ is the minimum value.

12. RCIF as a function of Dundurs Parameter for glass ceramic Resistan ${ }^{\mathrm{TM}}-\mathrm{G} 1$. Shown RCIF values from indentation are averages. The impact response of $\mathrm{Si}_{3} \mathrm{~N}_{4}$ is the minimum value.

13. Comparison of impact and indentation responses of $\mathrm{Si}_{3} \mathrm{~N}_{4}$ spheres into four different target tile material. 


\section{LIST OF FIGURES (Continued)}

14. RCIF as a function of sphere material elastic modulus for three target glass materials: Starphire ${ }^{\circledR}$ SLS, BOROFLOAT ${ }^{\circledR}$ BS, and glass-ceramic Resistan ${ }^{\text {TM}}-G 1$. Shown RCIF values from indentation are averages.

15. RCIF as a function of Dundurs Parameter for three target glass materials: Starphire $^{\circledR}$ SLS, BOROFLOAT ${ }^{\circledR}$ BS, and glass-ceramic Resistan ${ }^{\text {TM-G1. Shown }}$ RCIF values from indentation are averages. Note Dundurs Parameter is calculated for each target material and thus the same sphere materials do not have the same Dundurs Parameter.

16. RCIF of $\mathrm{Si}_{3} \mathrm{~N}_{4}$ indenter on glass ceramic Resistan ${ }^{\mathrm{TM}}-\mathrm{G} 1$ at approximate locations. Red is lowest value, violet is highest value. 


\section{LIST OF TABLES}

\section{Table}

Page

I. Summary of sphere materials used for testing of the glass glass-ceramic materials .... 5

II. Data collection parameters for velocity recording software. ................................ 12

III. Densities and elastic properties of target glass material. ................................... 14

IV. Diameter, mass, density, and elastic properties of sphere materials. ....................... 15

V. Minimum velocities producing ring crack and estimated minimum threshold ring crack initiation force from impact of $\mathrm{Si}_{3} \mathrm{~N}_{4}$ spheres into different target material.

VI. Ring crack initiation force (RCIF) from quasi-static spherical indentation testing using seven sphere materials into glass-ceramic Resistan ${ }^{\mathrm{TM}}-\mathrm{G} 1$.

VII. Ring crack initiation force (RCIF) from quasi-static spherical indentation testing using $\mathrm{Si}_{3} \mathrm{~N}_{4}$ spheres into different target material. 


\section{EXECUTIVE SUMMARY}

This report summarizes US Army TARDEC sponsored work at Oak Ridge National Laboratory (ORNL) involving low velocity $(<30 \mathrm{~m} / \mathrm{s}$ or $<65 \mathrm{mph})$ sphere impact testing of two materials from the lithium aluminosilicate family reinforced with different amounts of ceramic particulate, i.e., glass-ceramic materials, SCHOTT Resistan ${ }^{\mathrm{TM}}-\mathrm{G} 1$ and SCHOTT Resistan ${ }^{\mathrm{TM}}-\mathrm{L}$. Both materials are provided by SCHOTT Glass (Duryea, PA). This work is a follow-up to similar sphere impact studies completed by the authors on PPG's Starphire ${ }^{\circledR}$ soda-lime silicate glass and SCHOTT BOROFLOAT ${ }^{\circledR}$ borosilicate glass.

A gas gun or a sphere-drop test setup was used to produce controlled velocity delivery of silicon nitride $\left(\mathrm{Si}_{3} \mathrm{~N}_{4}\right)$ spheres against the glass ceramic tile targets. Minimum impact velocities to initiate fracture in the glass-ceramics were measured and interpreted in context to the kinetic energy of impact and the elastic property mismatch between sphere and target material. Quasistatic spherical indentation was also performed on both glass ceramics and their contact damage responses were compared to those of soda-lime silicate and borosilicate glasses. Lastly, variability of contact damage response was assessed by performing spherical indentation testing across the area of an entire glass ceramic tile.

The primary observations from this low velocity $(<30 \mathrm{~m} / \mathrm{s}$ or $<65 \mathrm{mph})$ testing were:

- Resistan ${ }^{\mathbf{T M}}-\mathrm{L}$ glass ceramic required the highest velocity of sphere impact for damage to initiate. Starphire ${ }^{\circledR}$ soda-lime silicate glass was second best, then Resistan ${ }^{\mathbf{T M}}-\mathrm{G} 1$ glass ceramic, and then BOROFLOAT ${ }^{\circledR}$ borosilicate glass.

- Glass-ceramic Resistan ${ }^{\mathrm{TM}}-\mathrm{L}$ also required the largest force to initiate ring crack from quasi-static indentation. . That ranking was followed, in descending order, by Starphire $^{\circledR}$ soda-lime silicate glass, Resistan ${ }^{\mathrm{TM}_{-} \mathrm{G} 1}$ glass ceramic, and BOROFLOAT $^{\circledR}$ borosilicate glass.

- Spheres with a lower elastic modulus require less force to initiate fracture in Resistan ${ }^{\text {TM}}-$ G1 from quasi-static spherical indentation. This indicates that friction

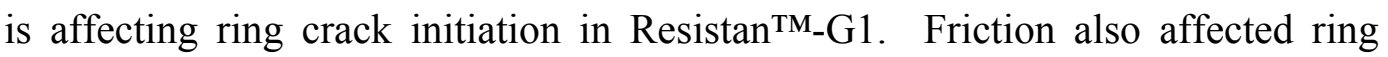


crack initiation in Starphire ${ }^{\circledR}$ soda-lime silicate and BOROFLOAT ${ }^{\circledR}$ borosilicate glasses. Among these three materials, friction was the most pronounced (largest slope in the RCIF-elastic modulus graph) in the Starphire ${ }^{\circledR}$ and least pronounced in the BOROFLOAT ${ }^{\circledR}$. The reason for this is not understood, but differences in deformation behavior under high contact stresses could be a cause or contributor to this.

- The force necessary to initiate contact-induced fracture is higher under dynamic conditions than it is under quasi-static conditions in Resistan ${ }^{\mathrm{TM}}-\mathrm{L}$ and Resistan ${ }^{\mathrm{TM}}$ G1 glass ceramics. This is a trend observed too in Starphire ${ }^{\circledR}$ and BOROFLOAT ${ }^{\circledR}$.

- There is a subtle indication there was intra-tile differences in sphericalindentation-induced ring crack initiation forces. This is not a material property nor is it exclusive to glass-ceramic Resistan ${ }^{\mathrm{TM}}-\mathrm{G} 1$ glass ceramic, rather, it is a statistical mechanical response to an accumulated history of processing and handling of that specific tile.

\section{DISCLAIMER}

Reference herein to any specific commercial company, product, process, or service by trade name, trademark, manufacturer, or otherwise, does not necessarily constitute or imply its endorsement, recommendation, or favoring by the United States Government or the Department of the Army (DoA). The opinions of the authors expressed herein do not necessarily state or reflect those of the United States Government or the DoA, and shall not be used for advertising or product endorsement purposes.

As the authors are not Government employees, this document was only reviewed for export controls, and improper Army association or emblem usage considerations. All other legal considerations are the responsibility of the author and their employer. 


\section{INTRODUCTION}

The impact of rock onto glass or transparent windshields is a common issue with vehicles. A rock can come in contact with the windshield by multiple means including being kicked up by another passing vehicle. Impact velocities will be in the range of vehicular speed. One of two things will occur when a rock impacts a glass windshield; either the glass will elastically respond and no damage is initiated or it will be permanently damaged (e.g., chipping or cracking). Such permanent damage can cause overall weakening of the window, or affect the optical properties of the glass, or both. By studying and quantifying the effect of rock impact on glass, the potential is established to improve resistance to the onset of undesirable permanent damage.

The meaning of the word "rock" can be quite ambiguous from a technical perspective. Rocks obviously can have different geometries (e.g., sizes and shapes) and compositions (e.g., densities and other material properties such as elastic modulus). Rocks generally have asymmetrical shapes with many edges. When a rock strikes a glass, one of many possible complicated and unpredictable loading scenarios can result based on its geometry and compositional inhomogeneity. It therefore can be difficult to assess a window's (i.e., target's) impact resistance when the impactor (i.e., rock or stone) can have so many independent parameters.

A sphere can be used to lessen the complexity of the event of a rock striking a glass target. A sphere of given size or diameter, density, and other physical properties can mimic or bracket those of a rock. The area and impact response of the target will be the same no matter what part of the sphere impacts it. This removes the unpredictable randomness of multiple edges and rotations of rock impact from the experiment. As we will show, it produces greater depth of understanding of the target system and material response. Additionally, sphere impact testing enables the use of established and simple Hertzian analytical modeling and subsequent interpretations. Ultimately though, an improved resistance to damage initiation with a spherical impact translates to an increased resistance to damage from an actual rock strike. 
The authors completed a study in which they evaluated the sphere impact of a soda-lime silicate glass [1]. In it, it was found:

- Frictional effects contributed to fracture initiation,

- For both dynamic impact and quasi-static indentation, spheres with a lower elastic modulus required less force to initiate fracture than spheres with a higher elastic modulus,

- Fracture sometimes initiated for kinetic energies between $\sim 150-1100 \mathrm{~mJ}$, however, it tended to occur when lower elastic modulus spheres were used, and

- The force necessary to initiate contact-induced fracture is higher under dynamic or impact conditions than it is under quasi-static indentation conditions.

Additionally, the authors evaluated the sphere impact of a borosilicate glass [2]. In that study, it was found:

- Frictional effects contribute to fracture initiation,

- In dynamic impact, spheres with a higher elastic modulus required less force to initiate fracture than spheres with a lower elastic modulus (opposite the trend of soda-lime silicate glass),

- In quasi-static indentation, spheres with a lower elastic modulus required less force to initiate fracture than spheres with a higher elastic modulus,

- Fracture sometimes initiated for kinetic energies between $\sim 20-150 \mathrm{~mJ}$, and

- The force necessary to initiate contact-induced fracture is higher under dynamic or impact conditions than it is under quasi-static indentation conditions.

In the present study, the sphere impact and quasi-static spherical indentation responses of two transparent, armor-grade, glass-ceramic glass were examined and contrasted to responses observed with soda-lime and borosilicate glasses. The test matrix is summarized in Table I. It is known the elastic property mismatch between a spherical indenter and target material will affect the force at which Hertzian ring cracking initiates in the target because of friction [1-3], but the 
examination of potential frictional effect was only examined with these glass ceramics using spherical indentation (and not ball impact) due to funding constraints.

Table I. Summary of sphere materials used for testing of the two glass glassceramic materials.

\begin{tabular}{|c|c|c|}
\multicolumn{1}{c|}{ Material Test } & \multicolumn{1}{c|}{ Resistan $^{\text {TM}}$-G1 } & Resistan $^{\text {TM}}-\mathbf{L}$ \\
\hline $\begin{array}{c}\text { Dynamic } \\
\text { Spherical Impact }\end{array}$ & $\mathrm{Si}_{3} \mathrm{~N}_{4}$ Sphere & $\mathrm{Si}_{3} \mathrm{~N}_{4}$ Sphere \\
\hline $\begin{array}{c}\text { Quasi-Static } \\
\text { Spherical Indentation }\end{array}$ & $\begin{array}{c}\text { All Sphere } \\
\text { Materials }\end{array}$ & $\mathrm{Si}_{3} \mathrm{~N}_{4}$ Sphere \\
\hline $\begin{array}{c}\text { Intra-tile } \\
\text { Spherical Indentation }\end{array}$ & $\mathrm{Si}_{3} \mathrm{~N}_{4}$ Sphere & None \\
\hline
\end{tabular}

\section{BASICS OF SPHERICAL IMPACT}

2.1. Estimating Impact Force from Impact Velocity

When a sphere impacts a target the amount of stress is determined by the impulse and the amount of contact area the force is acting on [4]. For spherical or Hertzian contact loading, and assuming frictionless contact (as classical Hertzian analysis inherently does), the stress, $\sigma_{\text {rad-max }}$, required to initiate ring cracking can be determined using

$$
\sigma_{r a d-\max }=\frac{1-2 v}{2 \pi} \frac{R C I F}{a^{2}}
$$

where $R C I F$ is the ring crack initiation force, $v$ is Poisson's ratio of the target material, and $a$ is the contact radius at the applied $R C I F$. The contact radius is determined using

$$
a=\left(\frac{3}{4} k \cdot R C I F \cdot R\right)^{1 / 3}
$$


where $\mathrm{R}$ is the sphere radius, and

$$
k=\frac{1-v_{s}^{2}}{E_{s}}+\frac{1-v_{t}^{2}}{E_{t}},
$$

where $E$ is the Young's modulus, and subscripts $s$ and $t$ represent the sphere and target, respectively.

At rock strike velocities, the velocity of impact is (or may be) known but not the associated applied force. Knight et al. [5] developed a relationship to calculate force from impact velocity by equating the kinetic energy of the sphere before impact to that of the total work, or

$$
\frac{1}{2}\left(\frac{4}{3} \pi \rho R^{3}\right) V^{2}=\int_{0}^{Z_{\operatorname{Max}}} P(z) d z
$$

where $\rho$ is the density of the sphere, $V$ is the velocity of the sphere, and $z$ is calculated by

$$
z=\frac{a^{2}}{R}
$$

This allows for the estimation of the maximum force, $P_{\max }$, from a dynamic impact as described by Timoshenko and Goodier [6] or

$$
P_{M a x}=\left(\frac{5}{3} \pi \rho\right)^{3 / 5}\left(\frac{3}{4} k\right)^{-2 / 5} V^{6 / 5} R^{2}
$$

If the impact initiates a ring crack, then $P_{M a x}$ in Eq. 6 can be equated to the ring crack initiation force $(R C I F)$, or 


$$
R C I F=P_{M a x}=\left(\frac{5}{3} \pi \rho\right)^{3 / 5}\left(\frac{3}{4} k\right)^{-2 / 5} V^{6 / 5} R^{2}
$$

The calculated impact $R C I F$ using Eq. 7 can then be compared to the $R C I F$ measured by quasistatic spherical indentation testing. Note that RCIF in Eq. 7 is independently related to sphere density $(\rho)$ and the elastic properties of the sphere and target (i.e., $k$ ).

It should be noted that the above equations are valid provided all deformation is linear elastic. If plastic or permanent deformation were to occur prior to ring crack initiation in either the sphere or target, then this introduces a violation of those assumptions and a level of complexity in the stress analysis that is beyond the scope of this report. The Hertzian theory assumption breaks down with steel spheres impacting soda-lime silicate glass (Knight et al. [5]) and, and as will be presented later in this report, the effects of the violation of that assumption was observed in the present study too for steel spheres.

\subsection{Comparing Different Sphere Materials}

Under contact conditions, spheres of different material will elastically deform differently when pushed against the same target material with the same applied force due to different elastic properties and therefore different Poisson's effect responses. While the same sphere diameter $(12.7 \mathrm{~mm})$ was used in all tests in the present study, ideally, to perform contact response studies involving different sphere materials, diameters should be used in context to the sphere material elastic properties so that the same contact area (and contact stress) are produced for the same applied compressive force for each sphere material. This is important because it enables a confident comparison between ring crack initiations generated by spheres made from dissimilar materials, namely, the target material should ring crack at the same applied compressive force with [sphere] materials of these two radii if there is a sustained frictionless Hertzian contact and if both the indenter and target material remain linearly elastic up to this force [3].

The necessary sphere sizes for dissimilar materials can be calculated by using the analysis of Johnson, et al. [7], namely 


$$
R_{1}\left[\frac{1-v_{1}}{G_{1}}+\frac{1-v_{t}}{G_{t}}\right]=R_{2}\left[\frac{1-v_{2}}{G_{2}}+\frac{1-v_{t}}{G_{t}}\right]
$$

or

$$
\frac{R_{2}}{R_{1}}=\frac{\frac{1-v_{1}}{G_{1}}+\frac{1-v_{t}}{G_{t}}}{\frac{1-v_{2}}{G_{2}}+\frac{1-v_{t}}{G_{t}}}
$$

where $R$ is sphere radius, $v$ is Poisson's ratio, and $G$ is shear modulus with subscripts 1,2 and $t$ representing sphere materials 1 and 2 , and the target material, respectively. Material 1 should be chosen to be of similar properties to the target material. The normalization of the contact area is not utilized in this report but discussed because of use in previous reports [1-2]

Even though the same sphere diameter was used in all these, the impact conditions they produced can still be correlated by developing a ratio of force, contact area, and stress using Eq. 1. With the known ring crack initiation stress and the force needed to produce the same stress with the constant contact radius, the normalized stress can be determined according to,

$$
\frac{1-2 v}{2 \pi} \frac{R C I F_{A C T}}{a_{A C T}^{2}}=\frac{1-2 v}{2 \pi} \frac{R C I F_{N O R M}}{a_{N O R M}^{2}}
$$

and can be simplified to

$$
\frac{P_{A C T}}{a_{A C T}^{2}}=\frac{P_{N O R M}}{a_{N O R M}^{2}} \text {. }
$$

Equation 11 allows for a normalized RCIF, $\mathrm{P}_{\mathrm{NORM}}$, to be calculated and compared. 
To represent this mismatch of elastic properties between the target and sphere, the Dundurs parameter, $\beta$, is a useful concept to utilize because it describes both the magnitude and direction of the elastic modulus mismatch between the contact pair. A positive $\beta$ defined here means the sphere's elastic properties produce greater stiffness than that of the target material while a negative $\beta$ means the target is stiffer than the sphere. The sign of $\beta$ also describes if the sphere or target is restricting the movement of the other under shear traction loading. $\beta$ can be calculated from [8]

$$
\beta=\frac{\frac{1-2 v_{t}}{G_{t}}-\frac{1-2 v_{s}}{G_{s}}}{2\left(\frac{1-v_{t}}{G_{t}}-\frac{1-v_{s}}{G_{s}}\right)}
$$

where $v$ is Poisson's ratio, and $G$ is shear modulus with subscripts $s$ and $t$ representing the sphere and target, respectively.

As will be shown, elastic property mismatch between the sphere and target material was found to affect RCIF response in the target Resistan ${ }^{\mathrm{TM}}-\mathrm{G} 1$ glass. That dependence in turn illustrates that frictional traction between the sphere and target glass affected Hertzian fracture initiation.

\subsection{Ring Crack Initiation at Dynamic vs. Quasi-Static Conditions}

The effects of the mismatch of elastic properties between the sphere and target on ring crack initiation (i.e., fracture initiation) have been systematically considered by the authors [1-2]. Quasi-static indentation testing, when teamed with acoustic emission detection, can easily identify the RCIF. RCIF is not so easy to detect during real-time sphere impact testing, but velocity is. By using Eq. 7, the RCIF of sphere impact testing can be estimated for different sphere materials by identifying the velocity at which ring crack initiations (a dynamic RCIF) and compared to RCIF responses measured quasistatically with spherical indentation. A difference in RCIF response is indicative of rate-effects affecting the dynamic RCIF. 


\section{GAS GUN, DROP TEST, TARGET GLASS, SPHERE IMPACTERS, AND SABOT}

Depending on the desired impact velocity, either a gas gun system (for velocities $>8 \mathrm{~m} / \mathrm{s}$ ) or a sphere-drop test system $(<8 \mathrm{~m} / \mathrm{s})$ was used. Descriptions of both follow along with descriptions of the target glass, the spheres, and the sabot for gas gun testing.

\subsection{Gas Gun Description}

A gas gun system was used for the majority of the testing. The air supply and barrel of the gas gun is shown in Fig. 1. The system uses compressed air controlled to predetermined pressure, which is then rapidly released via a regulator into a barrel. The barrel is preloaded with a sphere held by a sabot and the released air propels them both towards the glass sample. At the end of the muzzle the sabot is stopped propelling the sphere toward the glass target.

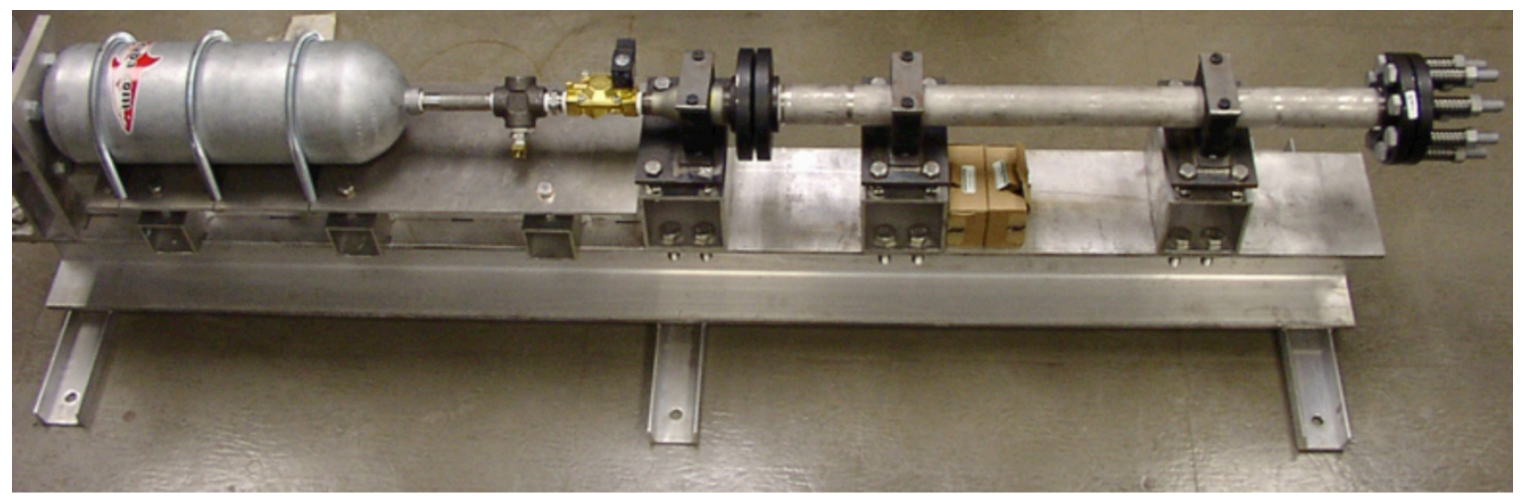

Figure 1. Gas gun assembly for low velocity sphere impact testing.

The sphere passes through a parallel beam laser detection system, illustrated in Fig. 2. The laser beams are spaced $100 \mathrm{~mm}$ apart and the sphere's time-of-flight is measured. The parallel laser beams were oriented vertically so the planar path of the sphere would interfere with the laser regardless its arch. The muzzle end, glass target, and general impact area are enclosed in plastic to maintain safe operating conditions. The velocity measurement system and impact area can be seen in Fig. 3 . 


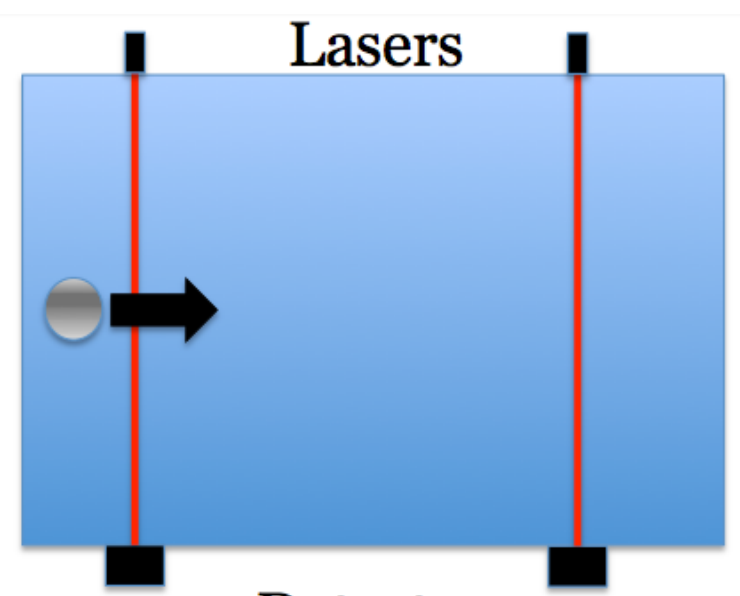

\section{Detectors}

Figure 2. Illustration of velocity measurement design.

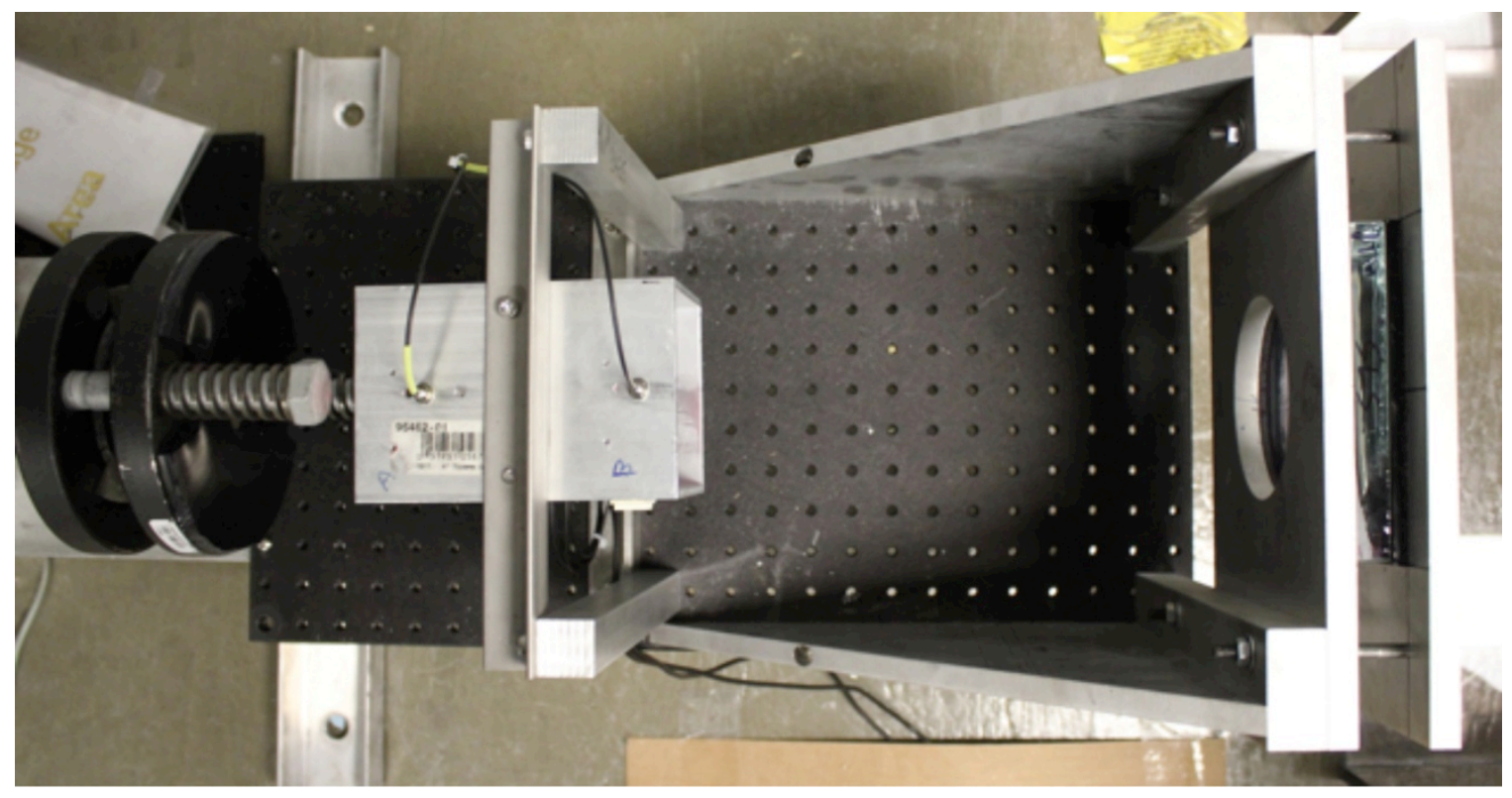

Figure 3. Top view showing end of barrel (left), velocity measurement device, and target glass (right of circular cut-out).

The velocity was recorded using an in-house developed LabView software program and a high-speed data acquisition card (National Instruments, Austin, TX). The time-of-flight data were collected with the parameters listed in Table II. 
Table II. Data collection parameters for velocity recording software.

\begin{tabular}{|c|c|}
\hline Minimum Sample Rate (Hz) & $4.0 \times 10^{4}$ \\
\hline Minimum Number of data points & 2000 \\
\hline Resolution $(\mathrm{sec})$ & $2.5 \times 10^{-5}$ \\
\hline Total Time $(\mathrm{sec})$ & 0.05 \\
\hline
\end{tabular}

\subsection{Drop Test Description}

The gas gun has a lower velocity limit $(\sim 8 \mathrm{~m} / \mathrm{s})$ due to the necessary pressure needed to eject the sphere along a straight path towards the glass target. A drop test was utilized to test ring crack initiation velocities below the lower limit of the gas gun. The drop test has a tube that allows the sphere to be controllably released from a certain height above the glass target. This drop test method also utilized the velocity measurement system but it was vertically positioned below the drop tube as shown in the Fig. 4.

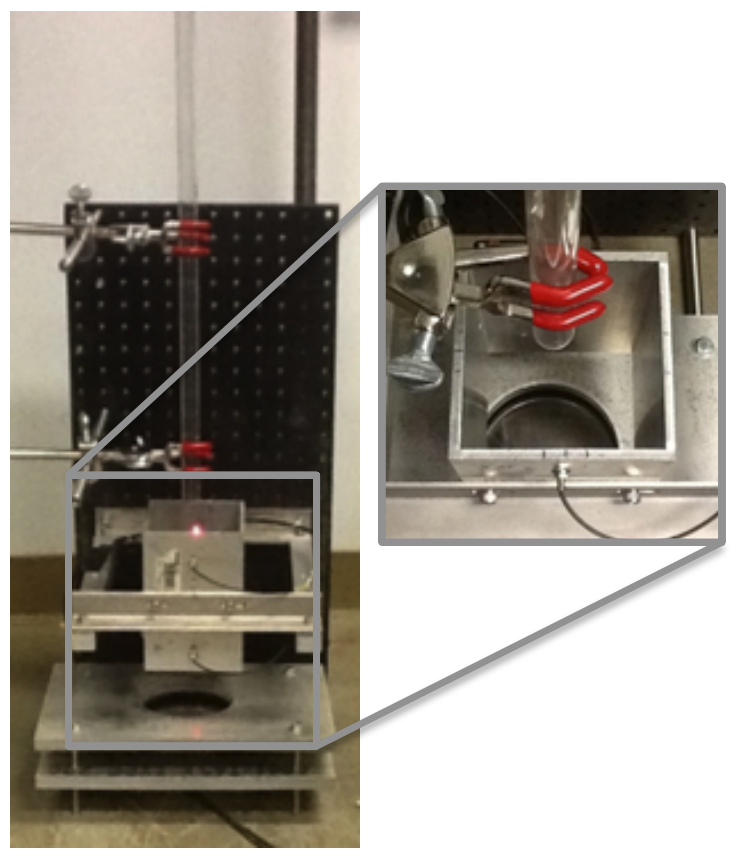

Figure 4. Drop test setup using the velocity measurement system, cutout showing impact area with target glass below. 


\subsection{Target Glass Description}

The investigated glass ceramics were Resistan ${ }^{\mathrm{TM}}-\mathrm{G} 1$ and Resistan ${ }^{\mathrm{TM}}-\mathrm{L}$. Both are materials from the lithium aluminosilicate family reinforced with different amounts of ceramic particulate, i.e., glass-ceramic materials, provided by SCHOTT Glass (Duryea, PA). Their responses were compared in this report against a previously tested soda-lime-silicate glass

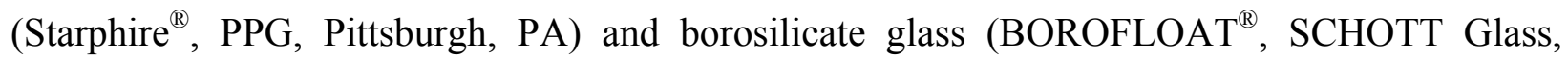
Duryea, PA) [1-2]. Examples of Resistan ${ }^{\mathrm{TM}}-\mathrm{G} 1$ and Resistan ${ }^{\mathrm{TM}}-\mathrm{L}$ glass-ceramic tiles are shown in Fig. 5. The Resistan ${ }^{\mathrm{TM}}-\mathrm{G} 1$ tiles had dimensions of $10.2 \times 10.2 \times 1.9 \mathrm{~cm}$ and the Resistan ${ }^{\mathrm{TM}}-\mathrm{L}$ was supplied in the form of a bilaminate of approximately $8 \mathrm{~mm}$ thick layers bonded together with a $2 \mathrm{~mm}$ thick layer of polyurethane. The side opposite the scoring-marked side was tested. The elastic modulus and Poisson's ratio of the Resistan ${ }^{\mathrm{TM}_{-} \mathrm{G} 1}$ were measured with resonance ultrasound spectroscopy (RUS) listed in Table III. However, their measurements with Resistan ${ }^{\mathrm{TM}}$-L were unobtainable with RUS because of their bilaminate form, so their values were taken to be those provided by SCHOTT.

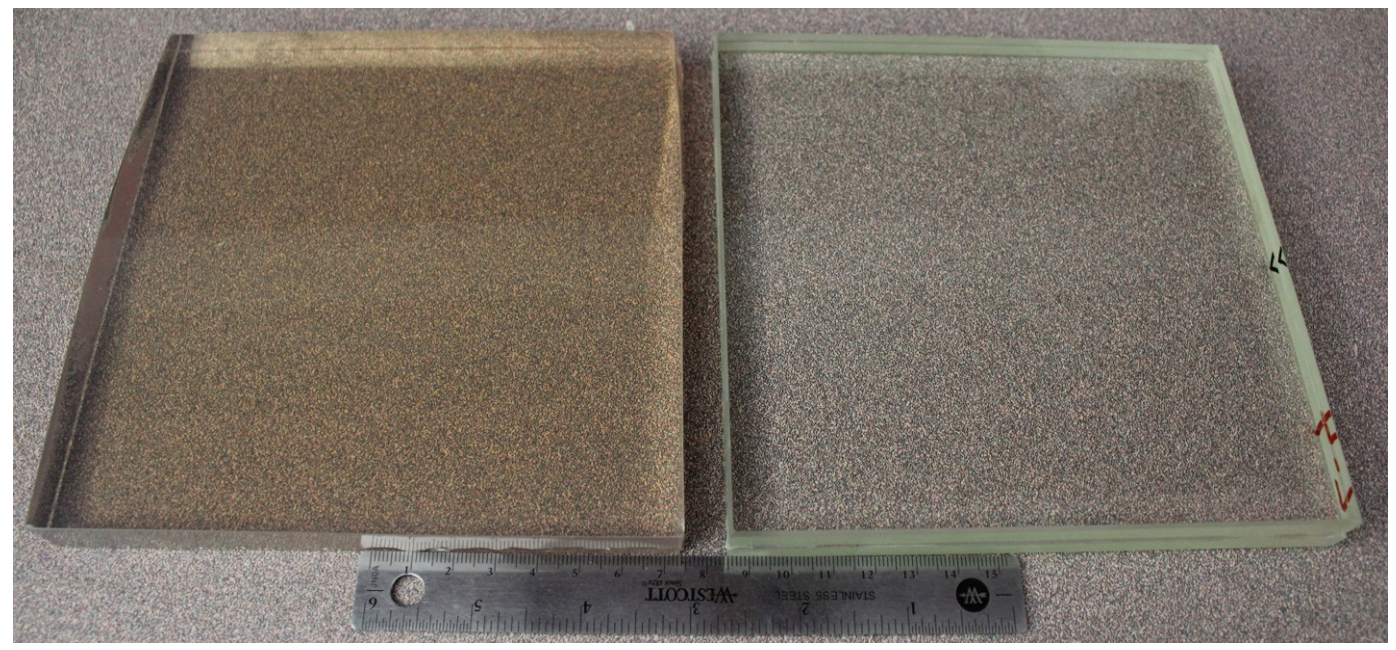

Figure 5. Photograph of glass-ceramic tiles Resistan ${ }^{\mathrm{TM}}-\mathrm{G} 1$ (left) and Resistan ${ }^{\mathrm{TM}}$-L (right). 
Table III. Densities and elastic properties of target glass or glass-ceramic material.

\begin{tabular}{|c|c|c|c|c|}
\hline $\begin{array}{c}\text { Target } \\
\text { Material } \\
\end{array}$ & $\begin{array}{c}\text { Density } \\
-r- \\
\left(\mathrm{g} / \mathrm{cm}^{3}\right)\end{array}$ & $\begin{array}{c}\text { Elastic } \\
\text { Modulus } \\
-E- \\
\text { (GPa) } \\
\end{array}$ & $\begin{array}{c}\text { Posson's } \\
\text { Ratio } \\
-v-\end{array}$ & $\begin{array}{c}\text { Shear } \\
\text { Modulus } \\
-G \text { - } \\
\text { (GPa) } \\
\end{array}$ \\
\hline $\begin{array}{c}\text { BOROFLOAT }^{\mathbb{B}} \\
\text { Borosilicate }[2,9]\end{array}$ & 2.22 & 63.1 & 0.180 & 26.7 \\
\hline $\begin{array}{c}\text { Starphire }^{\mathbb{R}} \text { Soda } \\
\text { Lime Silicate }[1,9]\end{array}$ & 2.49 & 73.1 & 0.203 & 30.4 \\
\hline $\begin{array}{l}\text { Glass Ceramic } \\
\text { Resistan }^{\mathrm{TM}_{-}} \mathrm{G} 1 \\
\end{array}$ & 2.53 & 94.3 & 0.247 & 37.8 \\
\hline $\begin{array}{l}\text { Glass Ceramic } \\
\text { Resistan }^{\mathrm{TM}}-\mathrm{L}\end{array}$ & 2.49 & $83^{*}$ & $0.225^{*}$ & $34^{*}$ \\
\hline
\end{tabular}

\subsection{Sphere Description}

Silicon nitride spheres were used for the impact testing, and their responses were contrasted against those of previous studies with soda-lime silicate and borosilicate glasses [1-2]. Other sphere materials were not used for impact testing due to project constraints.

For spherical indentation, numerous different sphere materials were used for testing and chosen in context to rock density. The average density was measured with several rocks from the grounds of the ORNL campus and was $2.80 \mathrm{~g} / \mathrm{cm}^{3}$, so several different sphere materials were considered to bracket that density. A $12.7-\mathrm{mm}(0.5 \mathrm{inch})$ diameter was used in all testing and images of each are shown in Fig. 6. The spheres, in order of increasing density as listed in Table IV, were purchased from commercial suppliers (Salem Ball, Canton, CT, for the BS glass, SLS glasses, and $\mathrm{ZrO}_{2}, \mathrm{McMaster}^{-C a r r}$, Atlanta, GA, for the alumina and steels, and Cerbec, East Granby, CT, for the silicon nitride spheres). The elastic modulus and Poisson's ratio of the spheres were determined using resonant ultrasounds spectroscopy (RUS) using a method developed by the author [10]. 
Table IV. Diameter, mass, density, and elastic properties of sphere materials.

\begin{tabular}{|c|c|c|c|c|c|c|}
\hline Material & $\begin{array}{c}\text { Diameter } \\
\text { (cm) }\end{array}$ & $\begin{array}{c}\text { Mass } \\
\text { (g) }\end{array}$ & $\begin{array}{l}\text { Density } \\
\left(\mathrm{g} / \mathrm{cm}^{3}\right)\end{array}$ & $\begin{array}{c}\text { Elastic } \\
\text { Modulus } \\
\text { - E - } \\
\text { (GPa) }\end{array}$ & $\begin{array}{c}\text { Poisson's } \\
\text { Ratio } \\
-v-\end{array}$ & $\begin{array}{c}\text { Shear } \\
\text { Modulus } \\
\text { - G - } \\
\text { (GPa) }\end{array}$ \\
\hline Borosilicate & 1.27 & 2.3869 & 2.22 & 62 & 0.20 & 26 \\
\hline Soda Lime Silicate & 1.27 & 2.6961 & 2.51 & 73 & 0.23 & 30 \\
\hline Silicon Nitride & 1.27 & 3.3890 & 3.16 & 315 & 0.27 & 124 \\
\hline Alumina & 1.27 & 4.1902 & 3.91 & 375 & 0.23 & 152 \\
\hline Zirconia & 1.27 & 6.5277 & 6.09 & 216 & 0.32 & 82 \\
\hline Steel (Carbon) & 1.27 & 8.3812 & 7.81 & 206 & 0.29 & 80 \\
\hline Steel (Chrome) & 1.27 & 8.3888 & 7.82 & 205 & 0.32 & 78 \\
\hline
\end{tabular}

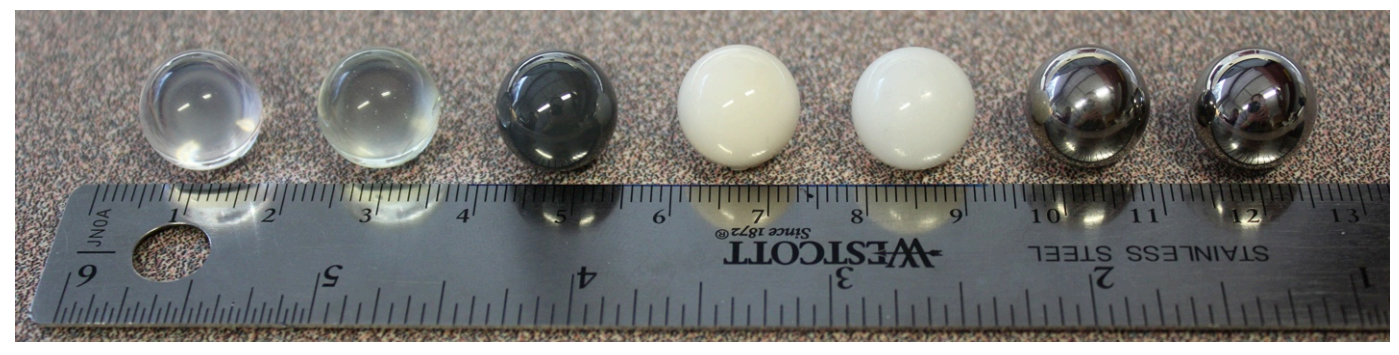

Figure 6. Spheres used for impact testing (from left to right): borosilicate (BS) glass, soda-lime silicate (SLS) glass, silicon nitride $\left(\mathrm{Si}_{3} \mathrm{~N}_{4}\right)$, alumina $\left(\mathrm{Al}_{2} \mathrm{O}_{3}\right)$, zirconia $\left(\mathrm{ZrO}_{2}\right)$, steel (carbon), and steel (chrome).

\subsection{Sabot Description}

A sabot was used for the gas-gun sphere shooting. The sabots were cast from a rigid polyurethane foam (FOAM-iT! $!^{\circledR} 15$, Smooth-On, Inc., Easton, PA) and were formed in a shape to retain a $12.7 \mathrm{~mm}$ diameter sphere. The sabot cradles the sphere as it accelerates down the barrel of the gas-gun. At the muzzle end of the barrel the fast traveling sabot was abruptly stopped launching the sphere toward the glass sample. 


\section{EXPERIMENTAL PROCEDURE}

\subsection{Gas Gun Calibration, Drop Test Calibration, and Unit Conversions}

The ratio of gas gun pressure to produced sphere velocity was determined in order to control the approximate velocity the sphere would hit the target. The relationship is shown in Fig. 7.

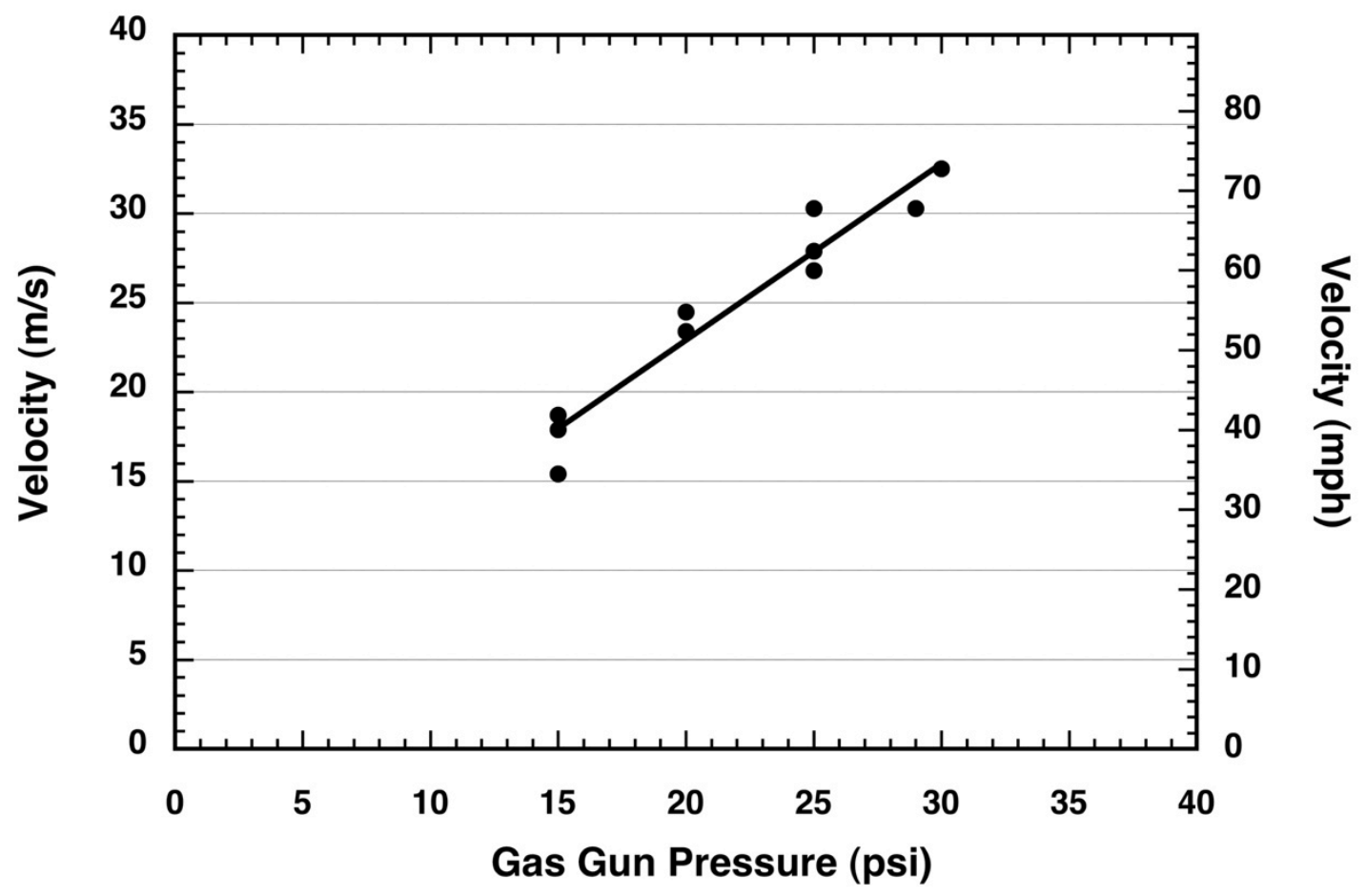

Figure 7. Gas gun pressure and resulting velocity.

The mass of the sabot was much greater than the mass of the sphere for all seven sphere materials therefore it was assumed that all spheres launched at approximately the same velocity for a given pressure. Regardless, the velocity of each launch was recorded. Occasionally the velocity measurement system failed to record. In those instances, the velocity was estimated (with a recognized uncertainty of \pm few $\mathrm{m} / \mathrm{s}$ ) using the linear fit shown in Fig. 7. 
The ratio of drop height to sphere velocity was determined to control the approximate speed of sphere impact on the target. Simple acceleration due to gravity could not be relied upon to determine the velocity due to the potential of air-drag in the tube. When the sphere leaves the tube (to pass through the velocity measurement system and strike the target) the acceleration due to gravity is determined. The relationship between drop height and impact velocity is shown in Fig. 8. Occasionally the velocity measurement system failed to record. In those instances, the velocity was estimated using the trend shown in Fig. 8.

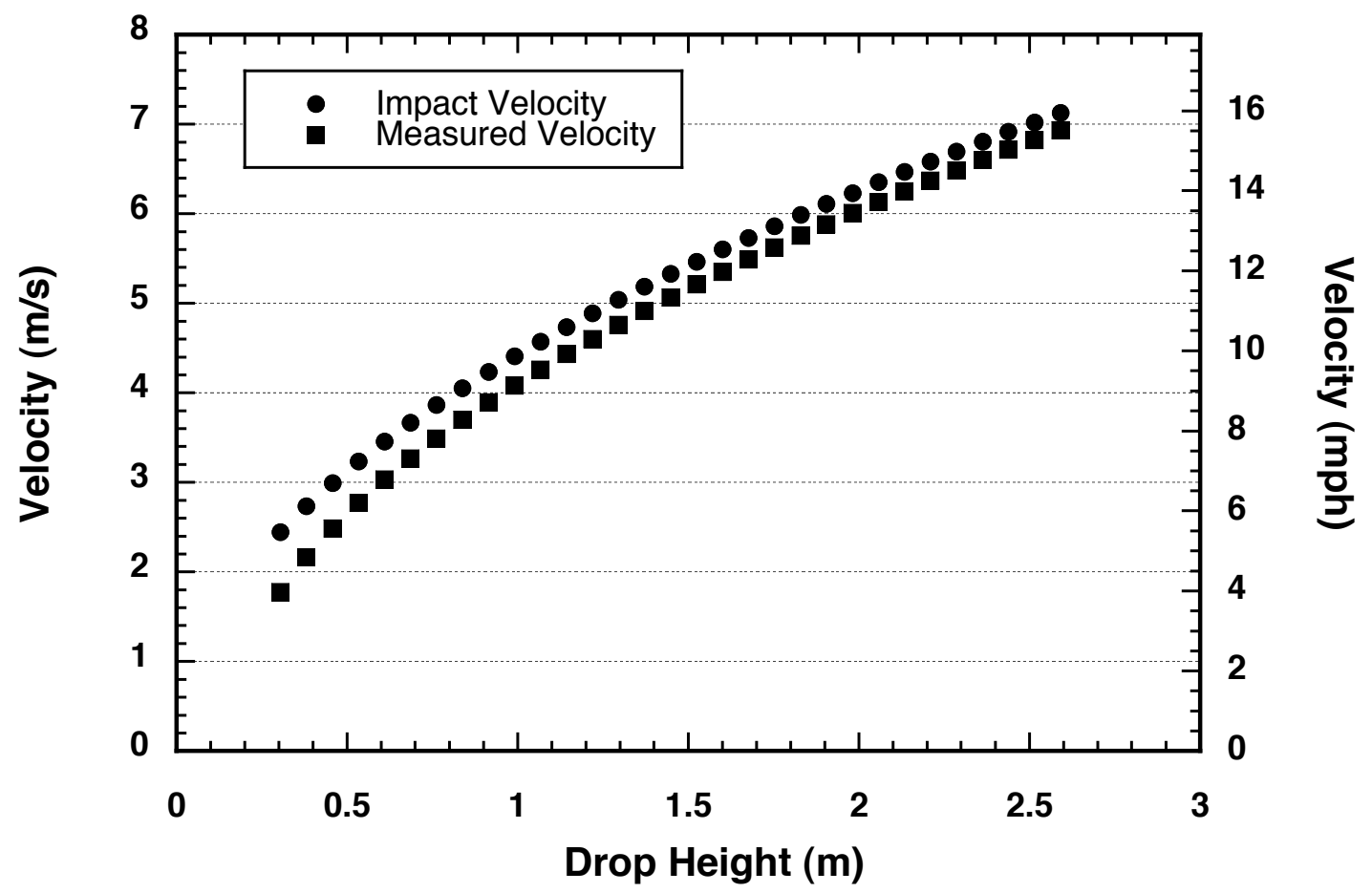

Figure 8. Relationship between drop height of spheres, resulting measured velocity, and resulting impact velocity corrected for continued acceleration due to gravity below velocity measurement system.

Metric and English units of velocity were both used, and their unit conversions are illustrated in Fig. 9 and listed in Eqs. 13-15. 


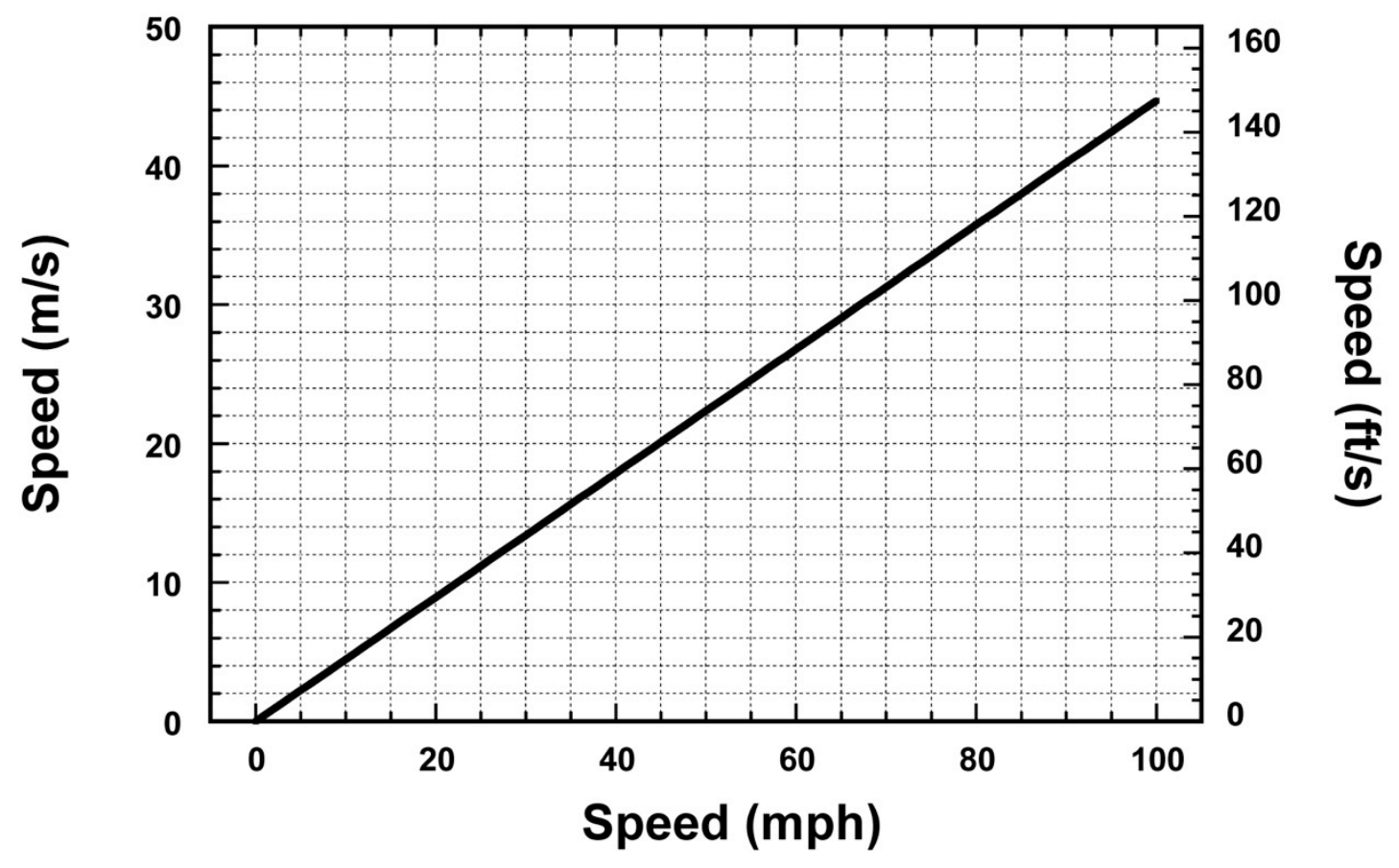

Figure 9. Velocity conversions between $\mathrm{m} / \mathrm{s}, \mathrm{mph}$, and $\mathrm{ft} / \mathrm{s}$.

$$
\begin{gathered}
1.00 \mathrm{~m} / \mathrm{s}=3.28 \mathrm{ft} / \mathrm{s}=2.24 \mathrm{mph} \\
1.00 \mathrm{mph}=1.47 \mathrm{ft} / \mathrm{s}=0.447 \mathrm{~m} / \mathrm{s} \\
1.00 \mathrm{ft} / \mathrm{s}=0.682 \mathrm{mph}=0.305 \mathrm{~m} / \mathrm{s}
\end{gathered}
$$

\subsection{Gas Gun Impact Test Procedure}

The target tile was loaded into position in the tile holder. The tile was sandwiched between two medium density rubber gaskets each having 100-mm-diameter holes co-located with the 100-mm-diameter hole in the holders (seen at far right in Fig. 3). A bottom rubber gasket was used to keep the placement height constant and position the target glass to be struck in the approximate center of the glass tile (100-mm-diameter exposed). Four bolts were torqued to $7 \mathrm{~N} \cdot \mathrm{m}(5 \mathrm{ft} \bullet \mathrm{lb})$ to uniformly compress the rubber gaskets. The relatively thick targets, coupled with the firm gripping of their margin for the sphere impact testing, resulted in insignificant 
outer-fiber deflection of the tiles occurring during the impact event. In support of that, no tiles ever bended a sufficient amount to cause fracture initiation from the back back.

The sabot and sphere were loaded on the breach side of the barrel and the barrel was then connected to the air gas supply. The gas chamber was adjusted to the desired pressure using input and blow-off valve switches. With the safety shields positioned, the main valve of the gas chamber was switched open to release the compressed air into the barrel behind the sabot, thus launching it. The velocity of the ejected sphere was recorded and the damage to the target sample optically examined with a compound optical microscope. The tile was reused if no crack was observed.

\subsection{Drop Impact Test Procedure}

The target tile was positioned and loaded into the holder and velocity measurement system identically to the gas gun as described in Section 4.2. This setup was oriented vertically under a drop test tube. A sphere was loaded into the tube at a designated height. The sphere was then released and allowed to drop freely. The velocity was measured during each drop and corrected for the free-fall acceleration between the velocity measurement system and the target. The tile was then inspected for damage. If no damage was seen, the tile remained in the test setup and a higher velocity (height) was used. The crack initiation force was defined as the lowest velocity (height) at which damage was seen (i.e., velocity necessary to initiate fracture).

\subsection{Quasi-Static Indentation}

Quasi-static spherical indentation was performed using an electromechanical test frame. The impact RCIF was shown in Eq. 7 to be independently related to sphere density and elastic properties of the sphere and target; however, for quasi-static indentation, sphere density does not affect RCIF, so this is a potential means to separate out this effect on RCIF. A schematic of the experimental setup is shown in Fig. 10. The same 12.7-mm-diameter spheres (Fig. 6) used for the impact testing were used as spherical indenters. The target tiles used for indentation were the same target tiles used for impact testing. A displacement rate of $0.002 \mathrm{~mm} / \mathrm{s}$ was used to 
compressively load the glass ceramic tile until crack initiation occurred followed by rapid unloading. Acoustic emission was monitored to determine the moment of ring crack initiation and its associated compressive force. Each indentation test occurred in an undamaged portion of the target tile. The BS and SLS glass test used a virgin sphere for every indent; the carbon and chrome steel spheres were randomly rotated but reused for each test. The zirconia, silicon nitride, and alumina reused the same sphere in the same orientation for every indent. The average, standard deviation, minimum, and maximum values were calculated for each sphere material.

Based on unanticipated test results previously seen by the authors with Borosilicate BS tiles, an additional test was performed to examine any evidence of location-dependent RCIF or RCIF variability on a single glass-ceramic Resistan ${ }^{\mathrm{TM}}-\mathrm{G} 1$ tile [2]. Using a silicon nitride spherical indenter, a virgin tile was indented in an evenly spaced 10 by 10 array. The resulting RCIF values were mapped.

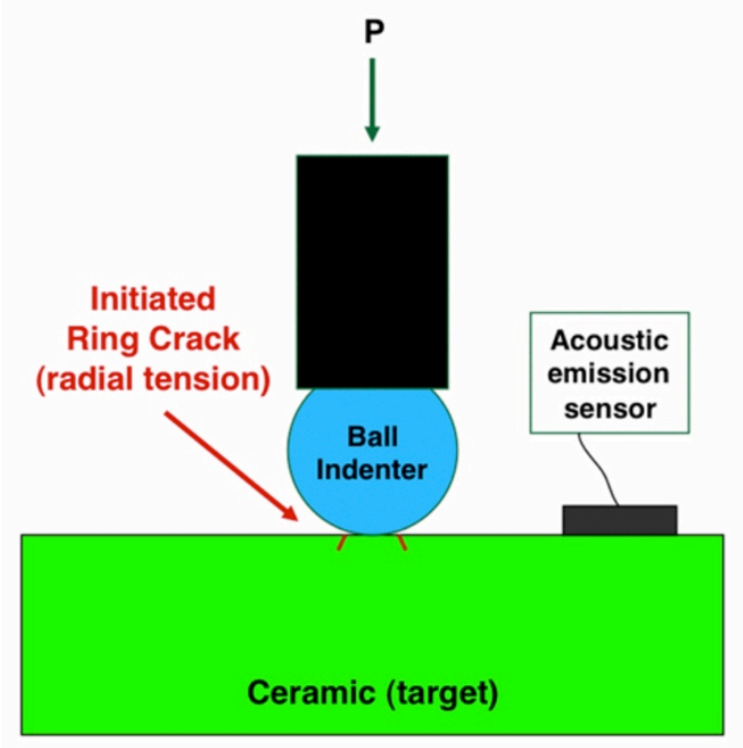

Figure 10. Schematic drawing of the ring crack initiation test configuration. An acoustic emission sensor was used to detect an acoustic event that was then linked to the ring crack initiation force. Target material is a glass ceramic tile. 


\section{RESULTS AND DISCUSSION}

\subsection{Impact Response and Comparison}

The minimum velocity needed to initiate ring crack (i.e., fracture) in the glass-ceramic tiles from $\mathrm{Si}_{3} \mathrm{~N}_{4}$ spheres is shown in Table V. For comparison the $\mathrm{Si}_{3} \mathrm{~N}_{4}$ impact data of the BOROFLOAT $^{\circledR}$ borosilicate and Starphire ${ }^{\circledR}$ soda-lime silicate tiles from previous reports are also listed in Table $\mathrm{V}$ [1-2].

Among Resistan ${ }^{\mathbf{T M}}-\mathrm{G} 1$ glass ceramic, Resistan ${ }^{\mathbf{T M}}-\mathrm{L}$ glass ceramic, Starphire ${ }^{\circledR}$ soda-lime silicate glass, and BOROFLOAT ${ }^{\circledR}$ borosilicate, the Resistan ${ }^{\mathbf{T M}_{-}}$- glass ceramic required the highest velocity of sphere impact for damage to initiate. Starphire ${ }^{\circledR}$ was second best, then Resistan $^{\mathbf{T M}}-\mathrm{G} 1$, and then BOROFLOAT ${ }^{\circledR}$.

The estimated ring crack initiation force (RCIF) value listed in Table V was calculated using Eq. 7 with the listed velocity. The estimated minimum threshold ring crack initiation force (RCIF) with diameter normalization according to Eq. 11 is not calculated as it was in previous reports [1-2]. The maximum radial tensile stress was calculated using Eq. 1. The minimum threshold kinetic energy was calculated using the classical formulation of $1 / 2 \bullet m \bullet V^{2}$ where $m$ is mass of the sphere. 
Table V. Minimum velocities producing ring crack and estimated minimum threshold ring crack initiation force from impact of $\mathrm{Si}_{3} \mathrm{~N}_{4}$ spheres into different target materials. Two significant digits are reported and deemed representative.

\begin{tabular}{|c|c|c|c|c|}
\multicolumn{1}{c}{} & \multicolumn{1}{c}{$\begin{array}{c}\text { Minimum } \\
\text { Ring Crack } \\
\text { Telocity } \\
\text { Material }\end{array}$} & $\begin{array}{c}\text { Minimum } \\
\text { Threshold } \\
\text { RCIF } \\
\text { (N) }\end{array}$ & $\begin{array}{c}\text { Maximum } \\
\text { Radial } \\
\text { Tensile Stress } \\
\text { (MPa) }\end{array}$ & $\begin{array}{c}\text { Minimum } \\
\text { Threshold } \\
\text { Kinetic Energy } \\
\text { (mJ) }\end{array}$ \\
\hline $\begin{array}{c}\text { BOROFLOAT } \\
\text { Borosilicate [2] }\end{array}$ & 3.4 & 1300 & 380 & 19 \\
\hline $\begin{array}{c}\text { Starphire } \\
\text { Soda Lime } \\
\text { Silicate [1] }\end{array}$ & 12 & 8500 & 970 & 240 \\
\hline $\begin{array}{c}\text { Glass-Ceramic } \\
\text { Resistan }\end{array}$ & 7.1 & 3700 & 730 & 86 \\
\hline $\begin{array}{c}\text { Glass-G1 } \\
\text { Resistantamic }\end{array}$ & 17.5 & 10400 & 950 & 520 \\
\hline
\end{tabular}

\subsection{Indentation Response and Comparison}

The summary statistics from the quasi-static spherical indentation testing of the glassceramic Resistan ${ }^{\mathrm{TM}_{-} \mathrm{G} 1}$ with seven different material spheres is shown in Table VI. Only ring crack initiation force is collected from this test.

Glass-ceramic Resistan ${ }^{\mathrm{TM}}$-L required the largest force to initiate ring crack from quasistatic indentation. . That ranking was followed, in descending order, by Starphire ${ }^{\circledR}$, Resistan ${ }^{\text {TM }}$ G1, and BOROFLOAT ${ }^{\circledR}$. This ranking was identical to that observed in the sphere impact testing, and this consistency is an indication that spherical indentation can be a useful method for ranking potential sphere impact testing of brittle materials. 
Table VI. Ring crack initiation force (RCIF) from quasi-static spherical indentation testing using seven sphere materials into glass-ceramic Resistan ${ }^{\mathrm{TM}}-\mathrm{G} 1$.

\begin{tabular}{|c|c|c|c|c|}
\multicolumn{1}{c|}{$\begin{array}{c}\text { Sphere } \\
\text { Material }\end{array}$} & $\begin{array}{c}\text { Average } \\
\text { RCIF } \\
(\mathbf{N})\end{array}$ & $\begin{array}{c}\text { Std Dev } \\
\text { RCIF } \\
(\mathbf{N})\end{array}$ & $\begin{array}{c}\text { Min } \\
\text { RCIF } \\
(\mathbf{N})\end{array}$ & $\begin{array}{c}\text { Max } \\
\text { RCIF } \\
(\mathbf{N})\end{array}$ \\
\hline BS glass & 1790 & 190 & 1380 & 2100 \\
\hline SLS glass & 3050 & 800 & 1360 & 4610 \\
\hline Carbon Steel & 2560 & 920 & 1340 & 4720 \\
\hline Chrome Steel & 2740 & 880 & 1120 & 4630 \\
\hline Zirconia & 3280 & 1110 & 960 & 5070 \\
\hline $\mathrm{Si}_{3} \mathrm{~N}_{4}$ & 1940 & 1040 & 660 & 4000 \\
\hline $\mathrm{Al}_{2} \mathrm{O}_{3}$ & 2290 & 970 & 1160 & 4720 \\
\hline
\end{tabular}

Spheres of a lower elastic modulus required less force to initiate a ring crack in glassceramic Resistan ${ }^{\mathrm{TM}}-\mathrm{G} 1$ during quasi-static spherical indentation. This is illustrated in Fig. 11 when RCIF is plotted against the sphere material elastic modulus and in Fig. 12 when plotted against Dundurs Parameter. This positive sloped trend seen in Figs. 11-12 are indicative of operative friction between sphere and target and its effects were previously observed by the authors in soda-lime-silicate and borosilicate glass [1-2]. The single impact datum from $\mathrm{Si}_{3} \mathrm{~N}_{4}$ is also shown on the plots. Among these three materials, friction was the most pronounced (largest slope in the RCIF-elastic modulus graph) in the Starphire ${ }^{\circledR}$ and least pronounced in the BOROFLOAT $^{\circledR}$. The reason for this is not understood, but differences in deformation behavior under high contact stresses could be a cause or contributor to this.

The RCIF response of the steel spheres, unlike those with the other five materials, are not well-fitted by the shown linear fit. This is due to the likelihood that the steel spheres were deforming, owing to its relatively low yield stress, resulting in an increase in the radius of curvature and a lower applied radial tensile stress produced in the target material. The other five materials remain linear elastic during their testing. This outlier behavior with steel has been observed before by the authors and others with spherical indentation [1-2, 5]. 


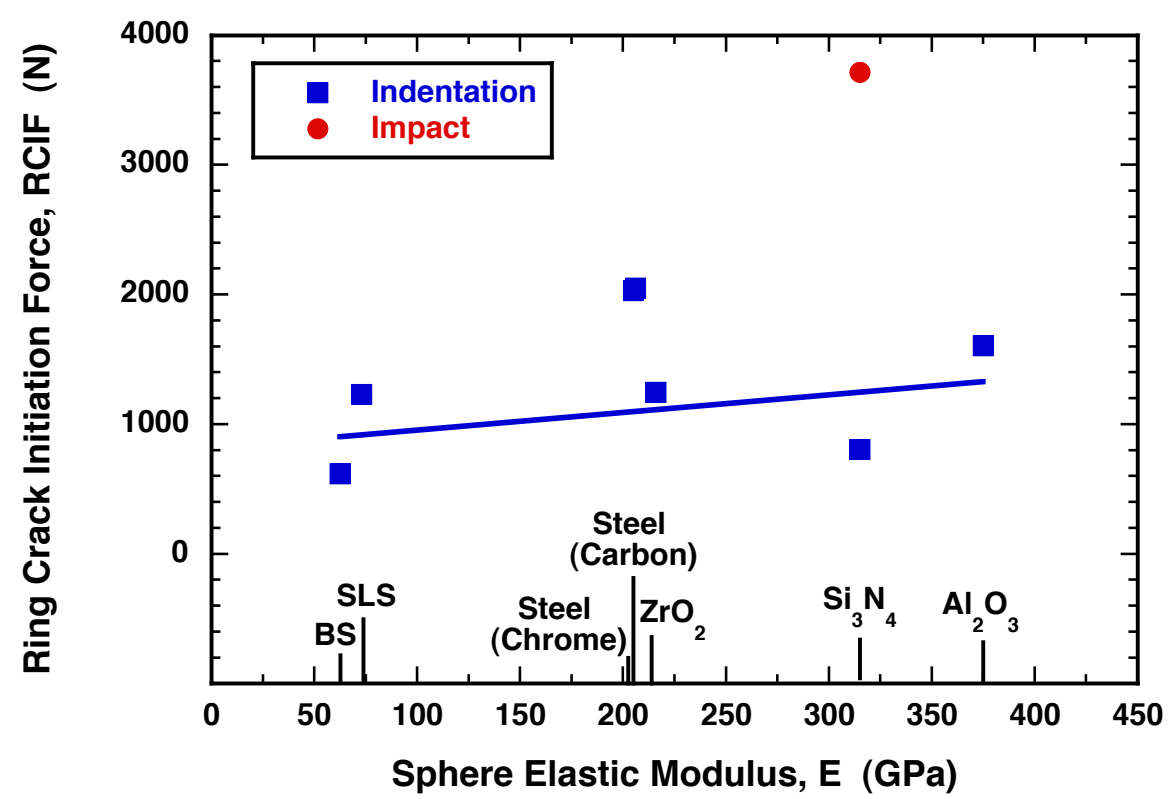

Figure 11. RCIF as a function of sphere material elastic modulus for glass ceramic Resistan ${ }^{\mathrm{TM}}-\mathrm{G} 1$. Shown RCIF values from indentation are averages. The impact response of $\mathrm{Si}_{3} \mathrm{~N}_{4}$ is the minimum value.

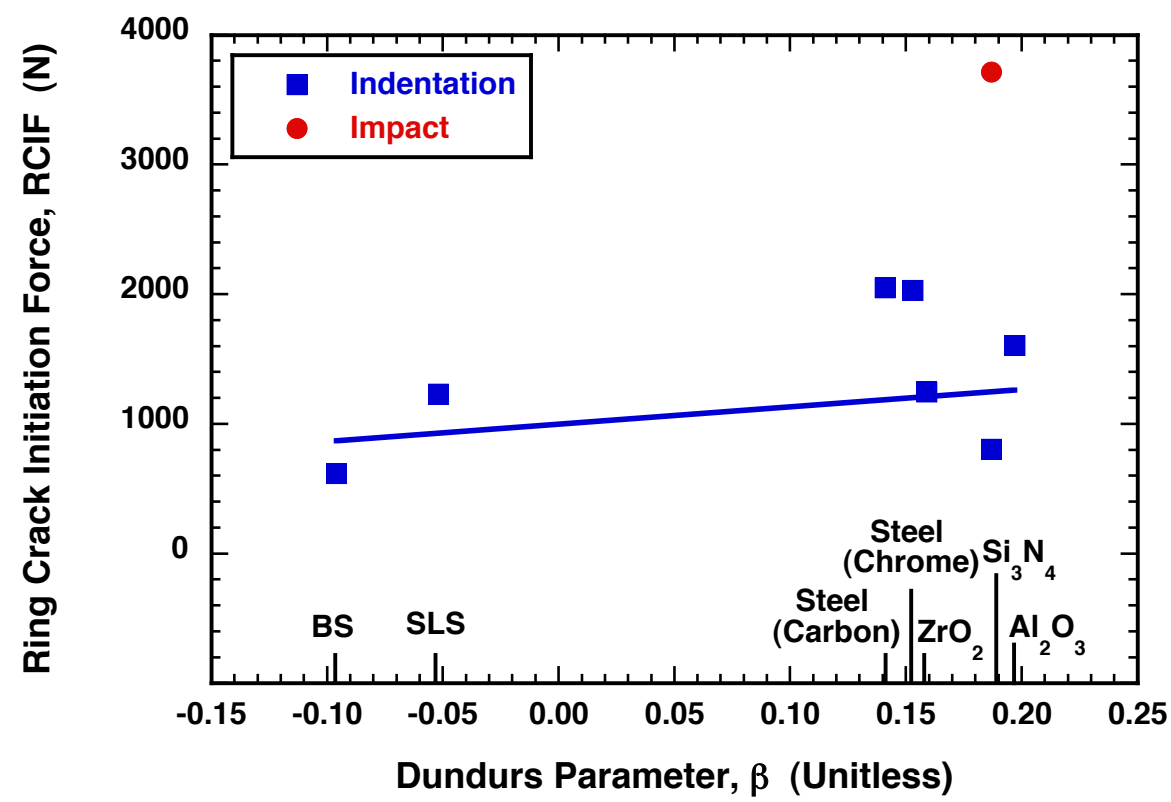

Figure 12. RCIF as a function of Dundurs Parameter for glass ceramic Resistan $^{\text {TM}}-$ G1. Shown RCIF values from indentation are averages. The impact response of $\mathrm{Si}_{3} \mathrm{~N}_{4}$ is the minimum value. 
The summary statistics from the quasi-static spherical indentation testing of $\mathrm{Si}_{3} \mathrm{~N}_{4}$ spheres onto the Resistan ${ }^{\mathrm{TM}}-\mathrm{G} 1$ and Resistan ${ }^{\mathrm{TM}}-\mathrm{L}$ is shown in Table VII. For comparison the $\mathrm{Si}_{3} \mathrm{~N}_{4}$ indentation data of the BOROFLOAT ${ }^{\circledR}$ borosilicate and Starphire ${ }^{\circledR}$ soda-lime silicate are also listed in Table VII [1-2].

Table VII. Ring crack initiation force (RCIF) from quasi-static spherical indentation testing using $\mathrm{Si}_{3} \mathrm{~N}_{4}$ spheres into different target material.

\begin{tabular}{|c|c|c|c|c|}
\multicolumn{1}{c}{$\begin{array}{c}\text { Target } \\
\text { Material }\end{array}$} & $\begin{array}{c}\text { Average } \\
\text { RCIF } \\
(\mathbf{N})\end{array}$ & $\begin{array}{c}\text { Std Dev } \\
\text { RCIF } \\
(\mathbf{N})\end{array}$ & $\begin{array}{c}\text { Min } \\
\text { RCIF } \\
(\mathbf{N})\end{array}$ & $\begin{array}{c}\text { Max } \\
\text { RCIF } \\
(\mathbf{N})\end{array}$ \\
\hline $\begin{array}{c}\text { BOROFLOAT } \\
\text { Borosilicate }\end{array}$ & 600 & 350 & 250 & 1550 \\
\hline $\begin{array}{c}\text { Starphire } \\
\text { Soda Lime } \\
\text { Silicate }\end{array}$ & 2820 & 1140 & 1300 & 5880 \\
\hline $\begin{array}{c}\text { Glass-Ceramic } \\
\text { Resistan }\end{array}$ & 1940 & 1040 & 660 & 4000 \\
\hline $\begin{array}{c}\text { Glass-G1 } \\
\text { Resistan }\end{array}$ & 4250 & 1840 & 2030 & 7800 \\
\hline
\end{tabular}

The minimum threshold RCIF from impact and the average RCIF for quasi-static indentation for all four different target glass tile materials using $\mathrm{Si}_{3} \mathrm{~N}_{4}$ are graphically shown in Fig. 13. 


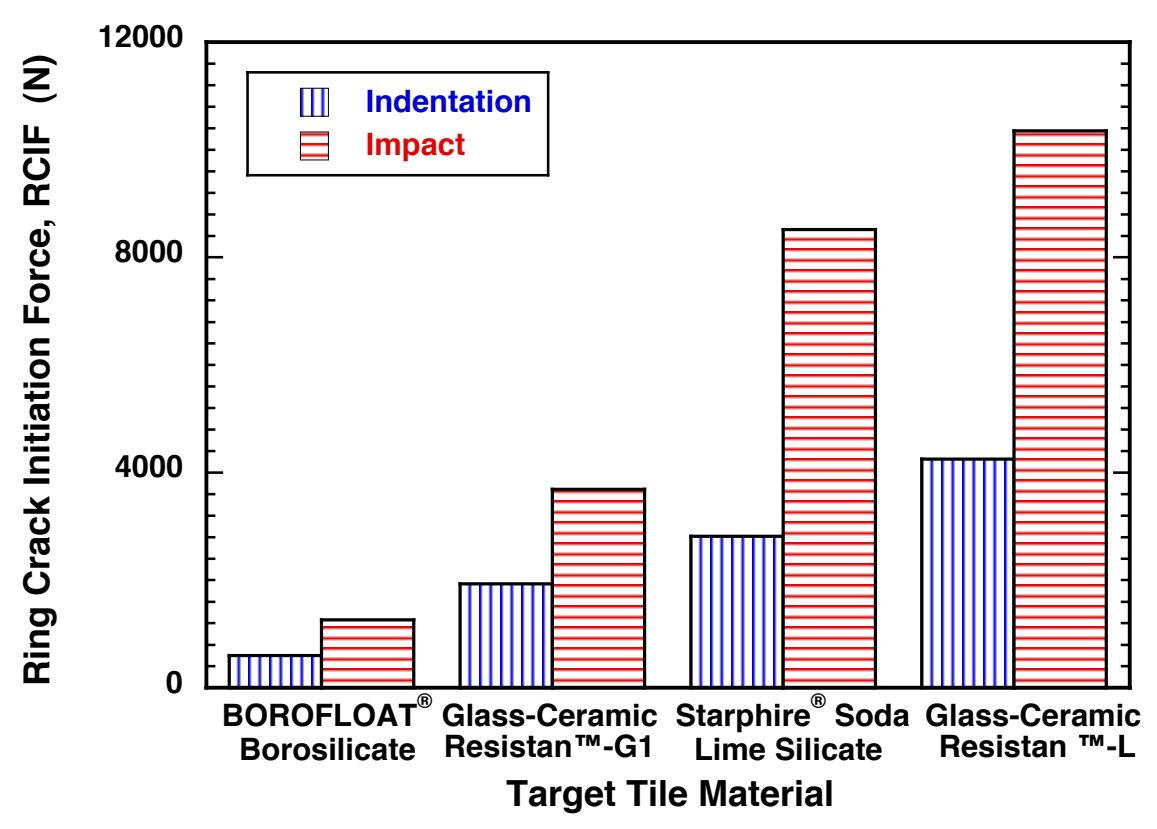

Figure 13. Comparison of impact and indentation responses of $\mathrm{Si}_{3} \mathrm{~N}_{4}$ spheres into four different target tile material.

The bilaminate glass-ceramic Resistan ${ }^{\mathrm{TM}}-\mathrm{L}$ requires the largest force to initiate ring crack for both impact and spherical indentation as shown in Fig. 13. The Starphire ${ }^{\circledR}$ SLS glass ranked second, followed by Resistan ${ }^{\mathrm{TM}}-\mathrm{G} 1$, and lastly the BOROFLOAT ${ }^{\circledR}$ BS glass. The force necessary to initiate ring cracking is always higher under dynamic conditions than under quasistatic conditions for all four materials. Tillet [11] and Johnson et al. [7] reported similar differences in quasi-static and dynamic sphere tests but they did not offer a potential explanation other than indicating it was due to a "rate effect".

The average RCIF of target glass material is plotted against sphere material elastic modulus in Fig. 14 and against Dundurs Parameter value in Fig. 15. In all three target materials, the spheres with a lower elastic modulus require less force to initiate ring cracking with the exception of the steels (previously discussed in Section 5.2.). Note the fitted line of the BOROFLOAT ${ }^{\circledR}$ BS in Fig. 14 has a slight, but statistically significant, positive slope but it may be difficult to see in the figure. 


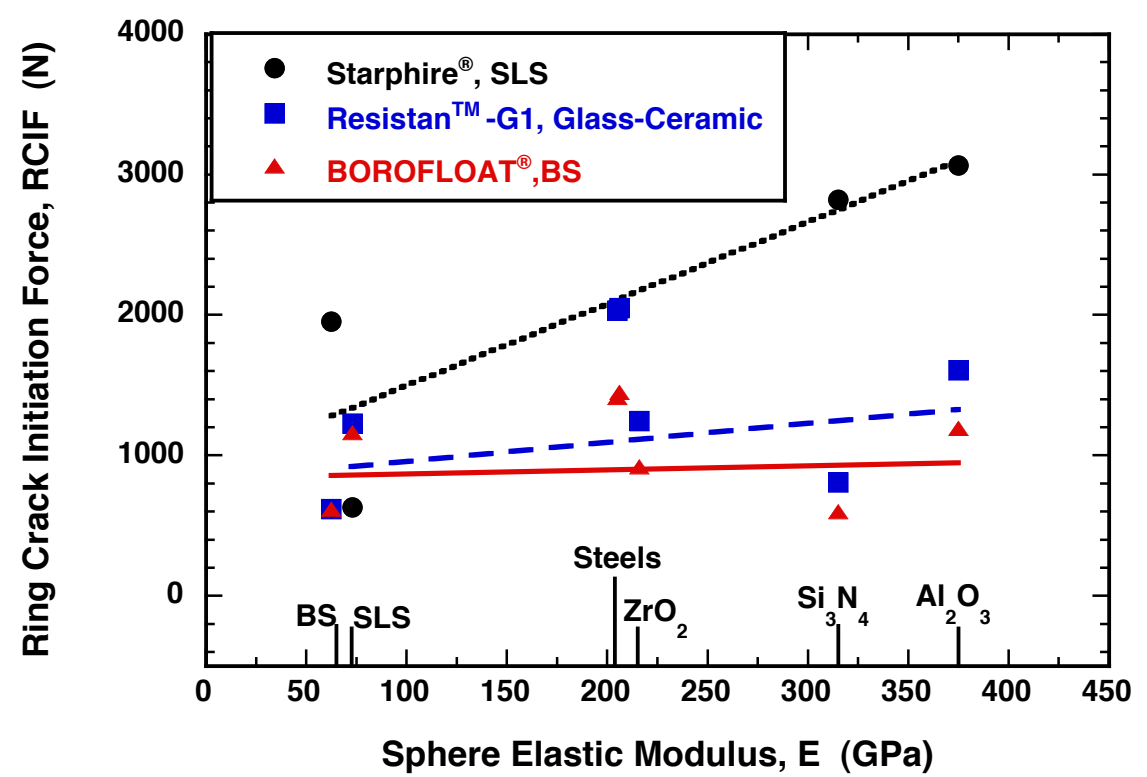

Figure 14. RCIF as a function of sphere material elastic modulus for three target glass materials: Starphire $^{\circledR}$ SLS, BOROFLOAT ${ }^{\circledR}$ BS, and glass-ceramic

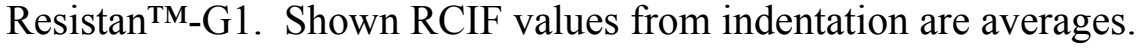

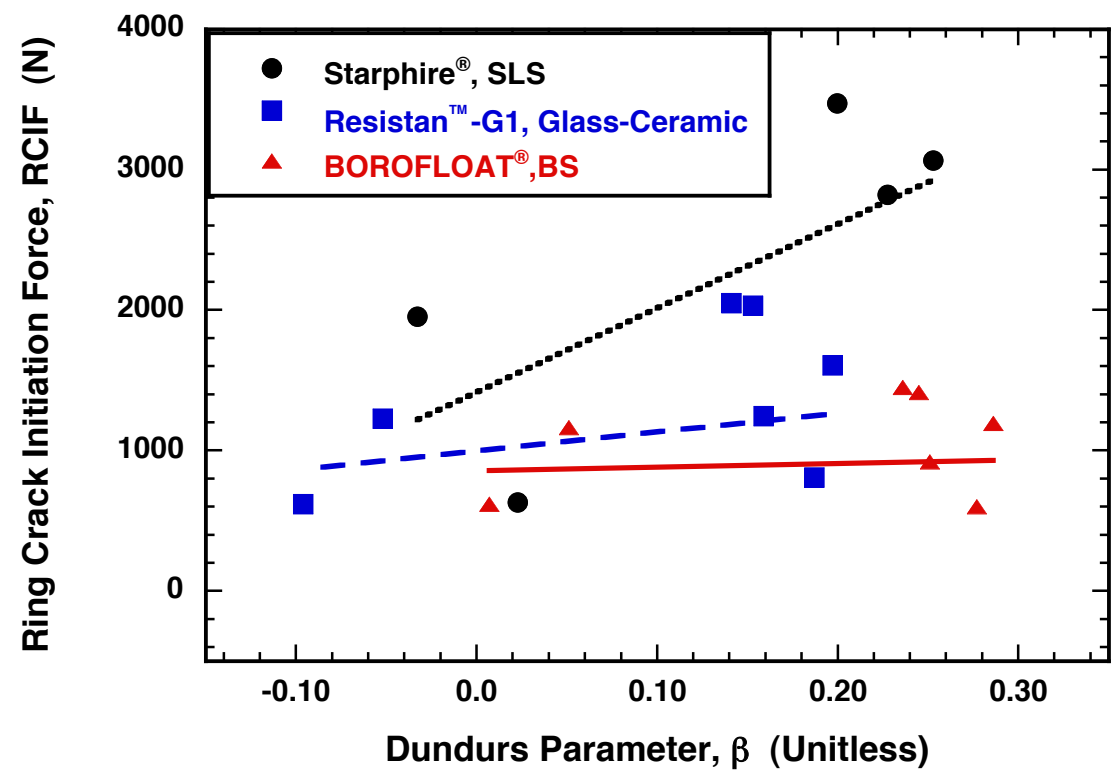

Figure 15. RCIF as a function of Dundurs Parameter for three target glass materials: Starphire ${ }^{\circledR}$ SLS, BOROFLOAT ${ }^{\mathbb{B}}$ BS, and glass-ceramic Resistan ${ }^{\mathrm{TM}}-\mathrm{G} 1$. Shown RCIF values from indentation are averages. Note 1: Dundurs Parameter is calculated for each target material and thus the same sphere materials do not have the same Dundurs Parameter for different target materials. Note 2: the line fitted to the BS data has a slight positive slope. 
The acoustic emission signals of the polyurethane-bonded Resistan ${ }^{\mathrm{TM}}-\mathrm{L}$ bilaminate during its spherical indentation were not detectable so its testing is not included in this spherical indentation test matrix. The reason for this is not known. If successful spherical indentation of tiles is sought using acoustic emission analysis, then this observation shows that "stand-alone" tiles need to be used.

\subsection{Location Dependent Indentation Response}

The summary of the location dependency of the RCIF across a glass-ceramic Resistan ${ }^{\mathrm{TM}_{-} \mathrm{G} 1}$ tile is displayed with color mapping. A linear color-coding is applied with red representing the lowest RCIF and violet representing the highest RCIF is shown in Fig. 16.

\begin{tabular}{|l|l|l|l|l|l|l|l|l|l|}
\hline 948 & 945 & 1233 & 881 & 1161 & 1947 & 1421 & 965 & 985 & 857 \\
\hline 969 & 1147 & 695 & 916 & 825 & 2163 & 1232 & 1827 & 1091 & 877 \\
\hline 1741 & 805 & 854 & 1282 & 837 & 1532 & 1060 & 1692 & 1098 & 944 \\
\hline 1501 & 1258 & 1005 & 1797 & 997 & 1873 & 1186 & 1576 & 1187 & 1044 \\
\hline 1710 & 2711 & 1590 & 2031 & 932 & 2164 & 1300 & 1689 & 1232 & 1047 \\
\hline 1743 & 2697 & 1327 & 1975 & 1205 & 1512 & 2013 & 1179 & 1039 & 1444 \\
\hline 1731 & 2770 & 1589 & 1890 & 1049 & 1859 & 1983 & 1861 & 1240 & 1073 \\
\hline 1714 & 1574 & 1545 & 886 & 2116 & 1633 & 1736 & 1245 & 854 & 979 \\
\hline 1601 & 1385 & 1107 & 2033 & 1985 & 1637 & 634 & 522 & 1284 & 1173 \\
\hline 1103 & 1271 & 1713 & 1058 & 1337 & 930 & 1710 & 884 & 1048 & 1002 \\
\hline
\end{tabular}

Figure 16. RCIF of $\mathrm{Si}_{3} \mathrm{~N}_{4}$ indenter on glass ceramic Resistan ${ }^{\mathrm{TM}}-\mathrm{G} 1$ at approximate locations. Red is lowest value, violet is highest value.

There is a subtle indication there was intra-tile differences in spherical indentation RCIF. This is not a material property nor is it exclusive to glass-ceramic Resistan ${ }^{\mathrm{TM}_{-} \mathrm{G} 1}$ glass ceramic, rather, it is a statistical mechanical response to an accumulated history of processing and handling of that specific tile. 


\section{SUMMARY}

- Among Resistan ${ }^{\mathbf{T M}}-\mathrm{G} 1$ glass ceramic, Resistan ${ }^{\mathbf{T M}}-\mathrm{L}$ glass ceramic, Starphire ${ }^{\circledR}$ soda-lime silicate glass, and BOROFLOAT ${ }^{\circledR}$ borosilicate, the Resistan ${ }^{\mathrm{TM}}-\mathrm{L}$ glass ceramic required the highest velocity of sphere impact for damage to initiate. Starphire ${ }^{\circledR}$ was second best, then Resistan ${ }^{\mathrm{TM}}-\mathrm{G} 1$, and then BOROFLOAT ${ }^{\circledR}$.

- Glass-ceramic Resistan ${ }^{\mathrm{TM}}-\mathrm{L}$ required the largest force to initiate ring crack from quasistatic indentation. . That ranking was followed, in descending order, by Starphire ${ }^{\circledR}$, Resistan $^{\mathrm{TM}}-\mathrm{G} 1$, and BOROFLOAT ${ }^{\circledR}$. This ranking was identical to that observed in the sphere impact testing, and this consistency is an indication that spherical indentation can be a useful method for ranking potential sphere impact testing of brittle materials.

- Spheres with a lower elastic modulus require less force to initiate fracture in Resistan ${ }^{\mathrm{TM}_{-}}$ G1 from quasi-static spherical indentation. This indicates that friction between the sphere and glass ceramic target affects ring crack initiation in the glass ceramic. Friction also affects ring crack initiation in Starphire ${ }^{\circledR}$ soda-lime silicate and BOROFLOAT ${ }^{\circledR}$ borosilicate glasses. Among these three materials, friction was the most pronounced (largest slope in the RCIF-elastic modulus graph) in the Starphire ${ }^{\circledR}$ and least pronounced in the BOROFLOAT ${ }^{\circledR}$. The reason for this is not understood, but differences in deformation behavior under high contact stresses could be a cause or contributor to this.

- The force necessary to initiate contact-induced fracture is higher under dynamic conditions than it is under quasi-static conditions in Resistan ${ }^{\mathrm{TM}}-\mathrm{L}$ and Resistan ${ }^{\mathrm{TM}}-\mathrm{G} 1$ glass ceramics and is a trend observed too in Starphire ${ }^{\circledR}$ and BOROFLOAT ${ }^{\circledR}$.

- There is a subtle indication there was intra-tile differences in spherical indentation RCIF. This is not a material property nor is it exclusive to glass-ceramic Resistan ${ }^{\mathrm{TM}}-\mathrm{G} 1$ glass ceramic, rather, it is a statistical mechanical response to an accumulated history of processing and handling of that specific tile.

- The acoustic emission signals of the polyurethane-bonded Resistan ${ }^{\mathrm{TM}}-\mathrm{L}$ bilaminate during its spherical indentation were not detectable. The reason for this are not known. If successful spherical indentation of tiles is sought using acoustic emission analysis, then this observation shows that "stand-alone" tiles need to be used. 


\section{REFERENCES}

[1] A. A. Wereszczak, E. E. Fox, T. G. Morrissey, and D. J. Vuono, "Low Velocity Sphere Impact of a Soda Lime Silicate Glass," ORNL/TM-2011/259, October, 2011.

[2] T. G. Morrissey, M. K. Ferber, A. A. Wereszczak, and E. E. Fox, "Low Velocity Sphere Impact of a Borosilicate Glass" ORNL/TM-2012/60 Report, May 2012

[3] A. A. Wereszczak, W. L. Daloz, K. T. Strong, Jr., and O. M. Jadaan, "Effect of Indenter Elastic Modulus on Hertzian Ring Crack Initiation in Silicon Carbide," Int. J. Appl. Cer. Tech., 8:885-94 (2011).

[4] A. D. Peralta and H. Yoshida, "Design of Impact-Resistant Ceramic Structural Components," Chapter 28 in Ceramic Gas Turbine Component Development and Characterization, Volume 2, Eds. M. van Roode, M. K. Ferber, and D. W. Richerson, ASME Press, New York, 2003.

[5] C. G. Knight, M. V. Swain, and M. M. Chaudhri, "Impact of Small Steel Spheres on Glass Surfaces”, J. Mat. Sci., 12:1573-86 (1977).

[6] S. Timoshenko and J. N. Goodier, Theory of Elasticity, McGraw-Hill Book Co., New York, 1951.

[7] K. L. Johnson, J. J O'Connor, and A. C. Woodward, "The Effect of the Indenter Elasticity on the Hertzian Fracture of Brittle Materials," Proc. R. Soc. London, 334:95117 (1973).

[8] J. Dundurs, "Edge-Bounded Dissimilar Orthogonal Elastic Wedges Under Normal and Shear Loading," J. Appl. Mech., 36:650-652 (1969).

[9] A. A. Wereszczak, T. P. Kirkland, K. T. Strong, Jr., and T. J. Holmquist, "ORNL QuasiStatic Mechanical Characterization and Analysis: FY09 Annual Report to TARDEC," ORNL/TM-2009/234 Report, December, 2009.

[10] A. A. Wereszczak, "Elastic Property Determination of WC Spheres and Estimation of Compressive Loads and Impact Velocities That Initiate Their Yielding and Cracking," Cer. Eng. Sci. Proc., [7] 27:211-223 (2006).

[11] J. P. A. Tillett, "Fracture of Glass by Spherical Indenters," Proc. Phys. Soc. B., 69:47-54 (1956). 


\section{ACKNOWLEDGEMENTS}

Research performed under Work For Others funded by U.S. Army Tank-Automotive Research, Development and Engineering Center, under contract DE-AC-00OR22725 with UT-Battelle, LLC.

The authors wish to express sincere appreciation to A. Dolan of the U.S. Army Research, Development and Engineering Command - Tank-Automotive and Armaments Command for sponsoring this work, and SCHOTT Glass's K. Leighton and M. Davis for supplying the glass ceramic tiles for evaluation. Lastly, the authors thank ORNL's C. Ayers and R. Wiles and SCHOTT Glass's K. Leighton for their review of this report and helpful comments.

This submission was produced by a contractor of the United States Government under contract DE-AC05-00OR22725 with the United States Department of Energy. The United States Government retains, and the publisher, by accepting this submission for publication, acknowledges that the United States Government retains, a nonexclusive, paid-up, irrevocable, worldwide license to publish or reproduce the published form of this submission, or allow others to do so, for United States Government purposes. 
APPENDIX I

Sphere Impact of Resistan ${ }^{T M_{-}}$G

\begin{tabular}{c|c|c|c|c|c|c|}
$\begin{array}{c}\text { Sphere } \\
\text { Material }\end{array}$ & $\begin{array}{c}\text { Tressure } \\
\text { (psi) }\end{array}$ & $\begin{array}{c}\text { Height } \\
\text { (m) }\end{array}$ & $\begin{array}{c}\text { Velocity } \\
\text { (m/s) }\end{array}$ & $\begin{array}{c}\text { Energy } \\
(\mathbf{m J})\end{array}$ & $\begin{array}{c}\text { Visible } \\
\text { Damage }\end{array}$ & $\begin{array}{c}\text { P max } \\
\text { (N) }\end{array}$ \\
\hline $\mathrm{Si}_{3} \mathrm{~N}_{4}$ & & 2.515 & & & $\mathrm{n}$ & \\
\hline $\mathrm{Si}_{3} \mathrm{~N}_{4}$ & & 2.667 & & & $\mathrm{n}$ & \\
\hline $\mathrm{Si}_{3} \mathrm{~N}_{4}$ & & 2.819 & & & $\mathrm{n}$ & \\
\hline $\mathrm{Si}_{3} \mathrm{~N}_{4}$ & & 2.972 & & & $\mathrm{n}$ & \\
\hline $\mathrm{Si}_{3} \mathrm{~N}_{4}$ & & 3.124 & & & $\mathrm{y}$ & \\
\hline $\mathrm{Si}_{3} \mathrm{~N}_{4}$ & & 3.277 & & & $\mathrm{n}$ & 3120 \\
\hline $\mathrm{Si}_{3} \mathrm{~N}_{4}$ & & 3.277 & 6.2 & 66 & $\mathrm{n}$ & 3720 \\
\hline $\mathrm{Si}_{3} \mathrm{~N}_{4}$ & & 3.277 & 7.2 & 88 & $\mathrm{n}$ & 3620 \\
\hline $\mathrm{Si}_{3} \mathrm{~N}_{4}$ & & 3.277 & 7.0 & 84 & $\mathrm{y}$ & 3690 \\
\hline $\mathrm{Si}_{3} \mathrm{~N}_{4}$ & & 3.277 & 7.1 & 86 & $\mathrm{y}$ & \\
\hline $\mathrm{Si}_{3} \mathrm{~N}_{4}$ & & 3.277 & & & $\mathrm{n}$ & \\
\hline $\mathrm{Si}_{3} \mathrm{~N}_{4}$ & & 3.277 & & & & \\
\hline
\end{tabular}

*Blanks represent unrecorded data. 


\section{APPENDIX II}

Sphere Impact of Resistan ${ }^{\text {TM-L }}$

\begin{tabular}{|c|c|c|c|c|c|c|}
\hline $\begin{array}{c}\text { Sphere } \\
\text { Material }\end{array}$ & $\begin{array}{c}\text { Gas Gun } \\
\text { Pressure } \\
\text { (psi) } \\
\end{array}$ & $\begin{array}{c}\text { Ball Drop } \\
\text { Height } \\
(\mathbf{m})\end{array}$ & $\begin{array}{c}\text { Impact } \\
\text { Velocity } \\
(\mathrm{m} / \mathrm{s})\end{array}$ & $\begin{array}{c}\text { Kinetic } \\
\text { Energy } \\
(\mathrm{mJ})\end{array}$ & $\begin{array}{c}\text { Visible } \\
\text { Damage }\end{array}$ & $\begin{array}{c}P \text { max } \\
(\mathrm{N})\end{array}$ \\
\hline $\mathrm{Si}_{3} \mathrm{~N}_{4}$ & & 3.048 & & & $\mathrm{n}$ & \\
\hline $\mathrm{Si}_{3} \mathrm{~N}_{4}$ & & 3.048 & & & $\mathrm{n}$ & \\
\hline $\mathrm{Si}_{3} \mathrm{~N}_{4}$ & & 3.048 & & & $\mathrm{n}$ & \\
\hline $\mathrm{Si}_{3} \mathrm{~N}_{4}$ & 20 & & 13.4 & 307 & $\mathrm{n}$ & 7547 \\
\hline $\mathrm{Si}_{3} \mathrm{~N}_{4}$ & 29 & & 33.5 & 1902 & $\mathrm{y}$ & 22562 \\
\hline $\mathrm{Si}_{3} \mathrm{~N}_{4}$ & 15 & & 18.8 & 599 & $\mathrm{y}$ & 11280 \\
\hline $\mathrm{Si}_{3} \mathrm{~N}_{4}$ & 15 & & 20.8 & 733 & $\mathrm{y}$ & 12735 \\
\hline $\mathrm{Si}_{3} \mathrm{~N}_{4}$ & 13 & & & & $\mathrm{y}$ & \\
\hline $\mathrm{Si}_{3} \mathrm{~N}_{4}$ & 11 & & & & $\mathrm{y}$ & \\
\hline $\mathrm{Si}_{3} \mathrm{~N}_{4}$ & 11 & & & & $\mathrm{n}$ & \\
\hline $\mathrm{Si}_{3} \mathrm{~N}_{4}$ & 12 & & 17.5 & 519 & $y$ & 10351 \\
\hline $\mathrm{Si}_{3} \mathrm{~N}_{4}$ & 11 & & 16.3 & 450 & $\mathrm{n}$ & 9505 \\
\hline
\end{tabular}

*Blanks represent unrecorded data. 